Khazanah: Jurnal Studi Islam dan Humaniora

ISSN: 0215-837X (p); 2460-7606 (e), Vol. 18 (1), 2020, pp. 49-74

DOI: 10.18592/khazanah.v18i1.3473

Submit :05/02/2020 Review : 08/05/2020 Publish : 20/06/2020

\title{
SISI KEARIFAN LOKAL DALAM TERJEMAH AL-QUR`AN BERBAHASA BANJAR
}

\author{
Wardani \\ Universitas Islam Negeri Antasari Banjarmasin \\ mwardanibjm@gmail.com
}

\begin{abstract}
The local wisdom as perceived as particular knowledge is often contrasted to universal revealed knowledge of religion. This article is aimed at studying the local wisdom behind al-Qur'an dan Terjemahnya Bahasa Banjar (the Qur'ân and Its Translation into Banjarese language), arguing that the two kinds of knowledge, either particular or universal, interact each other. Employing the ethics philosophy's distinction between particular and universal, the discussion on the topic is focused on the description of local wisdom and the issues of particularity and universality, especially in relation to moral values embedded in cultural dimensions of local language. The steps start from comparing Indonesian and Banjarese translation of some Qur ânic vocabularies, then describing moral values in Banjarese culture in perceiving certain words, and finally searching for particular and universal dimensions of cultural ethics by comparing it with other ethics which is universally recognized. This article arrives at some conclusions. Firstly, the local wisdom is reflected in the forms of local moral values corresponding to the doctrines of the Qur ân. Secondly, in relation to the idea of particularity and universality of moral values, the local wisdom behind this translation contains the two aspects, due to the fact that both dimensions constitute elements which interact with each other. The local values also underlay the use of local vocabularies. It means that the particular aspect of local wisdom transforms to universal one too. Besides, local wisdom does not only mean local knowledge, but also means that it has general affinity with other cultures.
\end{abstract}

Keywords: Local Wisdom; Translation; Bububan; Banua; Papadaan

\begin{abstract}
Abstrak: Kearifan lokal sebagaimana dipersepsikan sebagai pengetabuan partikular sering dikontraskan dengan pengetahuan diwahyukan yang universal dalam agama. Artikel ini bemaksud mengkaji kearifan lokal dalam al-Qurân dan Terjemahnya Bahasa Banjar, untuk menunjukean bahwa dua jenis pengetahuan itu, baik yang partikular maupun yang universal, saling berinteraksi. Dengan menerapkan distingsi dalam filsafat etika antara yang partikular dan yang universal, diskusi tentang topik tersebut akan difokuskan pada deskripsi tentang kearifan lokal tersebut dan isu-isu tentang partikularitas dan universalitas, khususnya dalam bubungannya dengan nilai-nilai moral yang tertanam dalam dimensidimensi budaya bahasa lokal. Langkah-langkahnya dimulai dari membandingkan terjemah berbahasa Indonesia dan terjemah berbahasa Banjar terhadap beberapa kosa-kata al-Qur ân, lalu mendeskripsikan nilai-nilai moral dalam kultur Banjar mempersepsikan ungkapan-ungkapan tertentu, dan terakhir, mencari dimensi-dimensi partikular dan universal dari etika kultural dengan membandingkannya dengan etika lain yang diakui secara universal. Artikel ini sampai pada beberapa kesimpulan. Pertama, kearifan lokal Banjar tersebut terefleksikan dalam berbagai bentuk nilai-nilai moral yang sesuai dengan ajaran-ajaran alQur ân. Kedua, terkait dengan ide partikularitas dan universalitas nilai-nilai moral, kearifan lokal di balik terjemah ini memuat dua aspek tersebut, karena faktanya bahwa dua dimensi itu merupakan elemen yang saling berinteraksi satu sama lain. Nilai lokal itu juga mendasari penggunaan kosa-kata lokal. Itu artinya bahwa aspek partikular dari kearifan lokal berubah menjadi universal juga. Di samping itu,
\end{abstract}


kearifan lokal tidak hanya bermakna sebagai pengetabuan lokal, melainkan juga bermakna bahwa ia memiliki kesamaan dengan kultur-kultur lain.

Kata kunci: Kearifan Lokal; Terjemah; Bubuhan; Banua; Papadaan

\section{Pendahuluan}

Penerjemahan al-Qur`an telah lama dilakukan seiring dengan berbagai kebutuhan. Penerjemahan pertama dilakukan pada sekitar abad ke-8 dan ke-9 M ke bahasa Yunani, dan teks terjemah itu digunakan dalam Refutatio oleh Niketas dari Byzantium untuk kepentingan propaganda anti-Islam. ${ }^{1}$ Di Barat, misalnya, penerjemahan al-Qur`an dilakukan pertama kali ke bahasa Latin oleh Robert dari Ketton (Robertus Retenensis) dan terjemah tersebut selesai pada Juli 1143 M. Penerjemahan tersebut diinspirasi oleh gagasan Peter the Venerable ketika ia berkunjung ke Toledo. Kemudian ia membentuk tim untuk mempelajari semua persoalan terkait dengan Islam, dimulai dari penerjemahan al-Qur`an. ${ }^{2}$ Begitu juga, di dunia Muslim, khususnya di Indonesia, penerjemahan al-Qur an juga dilakukan. Penerjemahan al-Qur`an sudah lama dilakukan di Indonesia, dimulai dari Tarjumân alMustafíd karya Syekh 'Abd al-Ra ûf Singkel (1615-1693 M) pada abad ke-17 M. ${ }^{3}$ Upaya penerjemahan bahkan disertai dengan tafsir juga dilakukan oleh Mahmud Yunus pada 1935 dengan karyanya, Tafsir Qur ân Karîm, ${ }^{4}$ A. Hassan pada 1928 dengan al-Furqn, ${ }^{5}$ K.H. Munawar Cholil dengan Tafsir Hidayatur Rabman, Zainuddin Hamidi dan kawan-kawan pada 1959 dengan Tafsîr al-Qur an, H. M. Kasim Bakry dan kawankawan pada 1960 dengan Tafsir al-Qur anil Hakim. Upaya penerjemahan secara individual ini diteruskan oleh beberapa penerjemah, seperti H. B. Jassin, ${ }^{6}$ Muhammad Thalib (amir Majelis Mujahidin). ${ }^{7}$

${ }^{1}$ Christian Hegel, “An Early Anonymous Greek Translation of the Qur`an: The Fragments

${ }^{2}$ William Montgomery Watt, Bell's Introduction to the Qur ân (Edinburgh: Edinburgh University Press, 1970), 173.

${ }^{3}$ Karya ini sebagian merupakan terjemah al-Qur`an, namun juga berisi uraian lebih mendalam (tafsîr). Terjemah al-Fâtihah: 1-7, misalnya, disertai dengan uraian dari aspek qirấat. Lihat, lebih lanjut, 'Abd al-Ra ûf Singkel, Tarjumân al-Mustafid (Beirut: Dâr al-Fikr, 1990), 2. 'Namun, secara keseluruhan, karya ini tampak sebagai tafsir. Tentang asal-usul sumber karya ini, lihat D. A. Rinkes, Abdoerroef van Singkel: Bijdrage tot de Kennis van de Mystiek op Sumatra en Java (Heerenven: Hepkema, 1909), 31-32. Lihat Salman Harun, Mutiara al-Qur'an: Aktualisasi Pesan al-Qur'an dalam Kehidupan (Jakarta: Logos Wacana Ilmu, 1999), 199. Lihat juga Anthony H. Johns, "Islam in the Malay World: An Exploratory Survei with Some Reference to Quranic Exegesis" dalam Islam in Asia, Vol. II, Southeast and East Asia, edited by Raphael Israeli and Anthony H," Johns. Jerusalem: The Magnes Press, The Hebrew University, 1984, 123.

${ }^{4}$ Mahmud Yunus, Tafsir Qur`an Karim (Ciputat: Mahmud Yunus wa Dzurriyyah, 2015).

5A Hassan, al-Furqan : Tafsir Qur' n (Jakarta: Universitas al-Azhar Indonesia, 2010).

'Istianah, "Dinamika Penerjemahan Al-Qur'an: Polemik Karya Terjemah Al-Qur'an HB Jassin dan Tarjamah Tafsiriyah Al-Qur'an Muhammad Thalib," Maghza: Jurnal Ilmu Al-Qur'an dan Tafsir 1, no. 1 (2016): 41-56.

${ }^{7}$ Lihat Mohamad Yahya, "Peneguhan Identitas dan Ideologi Majelis Mujahidin Melalui Terjemah Al-Qur'an," RELIGLA, 2018, 188-208. Lihat juga Muhammad Muhammad, "Dinamika Terjemah Al-Qur'an (Studi Perbandingan Terjemah Al-Qur'an Kemenerian Agama RI dan Muhammad Thalib)," Jurnal Studi Imu-ilmu Al-Qur'an dan Hadis 17, no. 1 (2018): 1-24. 
Berbagai riset tentang beberapa aspek dan perspektif terjemah disampaikan oleh beberapa penulis dalam International Conference and Workshop bertema, The Translation of the Qur ân in Indonesia, kerjasama Albert-Ludwigs-Universität Freiburg dan Universitas Islam Negeri Sunan Kalijaga pada 30-31 Juli 2018 di UIN Sunan Kalijaga, Yogyakarta. Namun berbagai riset itu tidak menyoroti terjemah al-Qur`an berbahasa Banjar secara khusus sebagai karya tersendiri, melainkan hanya dalam karya-karya keislaman secara umum. ${ }^{8}$

Selain riset terpresentasi di forum ini, berbagai tulisan tentang terjemah alQur`an di Indonesia juga telah menyoroti aspek penerjemahan al-Qur`an dengan berbagai bahasa lain, atau sekte tertentu, seperti Ahmadiah, dalam tulisan Ahmad Najib Burhani yang menemukan bahwa terjemah Soedewo dari The Holy Qur an karya Muhammad Ali berpengaruh di Indonesia, yang berarti bahwa terjemah al-Qur`an di Indonesia lebih dipengaruhi oleh unsur luar, dibandingkan unsur lokal. Nasruddin Baidan hanya menyoroti problematika penerjemahan al-Qur'an dalam bahasa Indonesia dalam perspektif gramatikal, seperti penerjemah ungkapan bismi rabbika (atas nama Tuhanmu, seharusnya: "dengan nama Tuhanmu"). ${ }^{10}$

Penelitian tentang kajian al-Qur`an dalam literatur-literatur non-tafsir telah dilakukan, terutama dalam hal ini karya Syekh Muhammad Arsyad al-Banjarî, baik tentang mushbaf al-Qur ân yang ditulisnya maupun penafsirannya terhadap beberapa ayat dalam Sabîl al-Mubtadîn, Tuhfat al-Râghibîn, dan Kan₹ al-Ma'rifah, yaitu penelitian Fathullah Munadi: (a) Mushbaf Qira'at Syekh Mubammad Arsyad al-Banjarî dalam Sejarah Qira'at Nusantara (2010); ${ }^{11}$ (b) Syekh Mubammad Arsyad al-Banjarî dalam Konteks Kajian al-Qur'an di Nusantara (2011). ${ }^{12}$ Kajian khususnya tentang mushbaf Syekh Arsyad juga telah ditulis, yaitu oleh Abdan Syukri. ${ }^{13}$ Penelitian seperti ini memang signifikan dalam konteks mendeskripsikan fase-fase "embriologis" tafsir-tafsir Banjar, namun

${ }^{8}$ Dalam konferensi ini, tema tentang penerjemahan al-Qur`an, antara lain, tentang terjemah al-Qur`an ke bahasa Bugis (Faried F. Saenong), terjemah ke bahasa Jawa (Johanna Pink, Regina Zahara), terjemah ke bahasa Sunda (Jajang A. Rohmana, Irma Riyani, Izzah Faizah, dan Dadang Darmawan), terjemah ke bahasa Banjar (Wardatun Nadhiroh), terjemah al-Qur`an yang digunakan di dunia pendidikan (Ahmad Rafiq dan Fathurrofiq), ideologi politik dan peran media (Munirul Ikhwan dan Abdoel Halim), isu gender (Akhmad Supriadi, Muhammad Alfatih Suryadilaga). Satu-satu yang menyoroti terjemah al-Qur'an di Tanah Banjar adalah Wardatun Nadhiroh, namun ia hanya menyoroti terjemahan al-Qur`an dalam karya-karya keislaman umum, bukan pada terjemah al-Qur`an bahasa Banjar secara khusus.

${ }^{9}$ Ahmad Najib Burhani, "Sectarian Translation of the Qur'an in Indonesia: The Case of the Ahmadiyya," Al-Jami'ab: Journal of Islamic Studies 53, no. 2 (2015): 251-282.

${ }^{10}$ Nashruddin Baidan, "Problematika Penerjemahan al-Qur'an dalam Bahasa Indonesia," Indonesian Journal of Islamic Literature and Muslim Society 2, no. 1 (2017): 1-20.

${ }^{11}$ Fathullah Munadi, "Mushhaf Qira'at Syekh Muhammad Arsyad al-Banjarî dalam Sejarah Qira'at Nusantara” 9, no. 1 (2010): 60-75.

${ }^{12}$ Fathullah Munadi, Syekh Mubammad Arsyad al-Banjarî dalam Konteks Kajian al-Qur'an di Nusantara (Banjarmasin: Antasari Press, 2011).

${ }^{13}$ Lihat Abdan Syukri, "Mushhaf Syekh al-Banjari" dalam Fadhal Ar Bafadal dan Rosehan Anwar, Mushaf-mushaf kuno Indonesia, vol. 1 (Puslitbang Lektur Keagamaan, Badan Litbang Agama dan Diklat Keagamaan, 2005), 213-217. 
seharusnya hanya dilihat sebagai langkah awal dalam memahami perkembangan kajian al-Qur`an di tanah Banjar yang sesungguhnya baru berkembang belakangan.

Riset tentang terjemah al-Qur`an di Tanah Banjar pernah dilakukan oleh Wardatun Nadhiroh, namun hanya meneliti penafsiran H. Husin Kaderi dalam Sanjata Muimin, sebuah kumpulan doa-doa yang sebagian merujuk kepada ayat-ayat al-Qur'an tertentu yang ditafsirkan secara sporadis dan tentu saja karya ini sama sekali bukan sebuah karya tafsir. "Penafsiran", atau lebih tepat disebut sebagai "penggunaan" atau "penerapan" (tathbîq), ini dicontohkannya melalui penggunaan ayat dalam doa-doa dalam Sanjata Mu'min karya K.H. Husin Kaderi yang ia klasifikasikan sebagai "tafsir awam" (lay exegesis). Yang dimaksud dengan istilah ini, menurut Andreas Görke, sebagaimana dikutip penulis, adalah tafsir terhadap ayat alQur`an, dengan pemahaman sedemikian rupa yang tidak bisa dipertanggungjawabkan secara metodologi tafsir, karena perhatian utama yang dipentingkan adalah pengamalan ayat tertentu untuk kepentingan praktis, seperti perlindungan diri. Upaya ini dimaksudkan sebagai, apa yang diklaimnya, sebagai pribumisasi Islam. Sebenarnya, istilah "tafsir awam" tidak sepenuhnya bisa dilekatkan pada penafsiran ulama-ulama yang, meski bukan dikenal luas sebagai penafsir, seperti Syekh Arsyad, sebenarnya mengetahui prinsip-prinsip penafsiran, karena penyimpulan persoalan keislaman, baik teologi, fiqh, maupun tasawuf, dengan ayat-ayat al-Qur'an tertentu, meniscayakan pengetahuan tentang penafsiran. ${ }^{16}$

\footnotetext{
${ }^{14}$ Wardatun Nadhiroh, "Kitab Sanjata Mu'min Sebuah Bentuk Tafsir Awam di Tanah Banjar,” SUHUF Jurnal Pengkajian Al-Qur'an dan Budaya 11, no. 1 (2018): 119-143.

${ }^{15}$ Pembedaan antara "tafsir" dan "penerapan" (tathbîq) dikemukakan oleh al-Thabathabâ'î, sebagaimana dikutip oleh M. Quraish Shihab, "Membumikan al-Qur'an jilid 2: Memfungsikan wahyu dalam kehidupan," Jakarta: Lentera Hati, 2011, 559. Lihat juga Wardani Wardani, Trend Perkembangan Pemikiran Kontemporer: Metodologi Tafsir Al-Qur'an di Indonesia (Yogyakarta: Kurnia Kalam Semesta,
} 2017), 210, fn. 32 .

${ }^{16}$ Ulama yang tidak dikenal sebagai penafsir, karena tidak menulis secara khusus karya tafsir, tidak berarti tidak memahami dengan baik metodologi tafsir dan tidak pernah menafsirkan ayat alQur`an secara khusus, meski tidak dalam bentuk karya tafsir, semisalnya al-Syâthibî (ahli ushûl al-fiqh) dan al-Ghazâlî (teolog, faqîh, shûfî, karya tafsirnya yang masih kontroversial keberadaannya adalah Qânûn al-Ta wî́). Meski mereka tidak menulis karya khusus tentang metodologi tafsir, pemikiran mereka berdua yang meski tersebar, setelah direkonstruksi, memiliki orisinalitas dan menjadi alternatif secara distingtif bagi penafsiran. M. Amursid, "Hermeneutika Al-Qur'an Syâthibî; Telaah Gagasan alSyâthibî tentang Signifikasi Ke-Araban al-Qur'an," Analisis: Jurnal Studi Keislaman 16, no. 2 (2016): 169-188. Lihat juga Wardani, Maqâshid al-Syarîah Sebagai Paradigma Ideal-Moral Tafsir al-Qur'an: Perspektif Al-Syathibi (Banjarmasin: Antasari Press, 2018). Lihat juga Jacques Scheuer, "Avital Wohlman, Contrepoint entre le sens commun et la philosophie en Islam. Ghazali et Averroès. Traduction par Annie Laurent, 2008," Revue Théologique de Lowvain 39, no. 4 (2008): 567. Lihat juga Avital Wohlman, Al-Ghazali, Averroës and the interpretation of the Qur'an: common sense and philosophy in Islam (Routledge, 2009). Lihat Frank Griffel, "Al-Ghazali, Averroes and the Interpretation of the Qur' an: Common Sense and Philosophy in Islam," Journal of Islamic Studies 23, no. 1 (2012): 94-98. Lihat Muh Said, "Metodologi Penafsiran Sufistik: Perspektif Al-Gazali," Jurnal Diskursus Islam 2, no. 1 (2014): 142-168. Bandingkan dengan Martin Whittingham dalam al-Gazali and the Qur'an yang menyoroti inkonsistensi penafsirannya secara hermeneutis, lihat Martin Whittingham, Al-Ghazali and the Qur'an: one book, many meanings (Routledge, 2007). Bagi Görke, "tafsir awam" itu adalah tafsir dari orang yang tidak memiliki latar belakang pengetahuan yang mapan dalam bidang ilmu-ilmu keislaman dan 
Begitu juga, kajiannya tentang tradisi lisan dan tertulis al-Qur ${ }^{\prime}{ }^{17}{ }^{17}$ tidak menyentuh terjemah maupun tafsir sebagai produk karya ulama Banjar. Begitu juga, tidak ada kajian serius, kecuali beberapa skripsi S1 yang ditulis oleh mahasiswa, tentang berbagai tradisi-tradisi al-Qur ân, seperti tradisi Yasinan, membaca alQur'ân, baamalan (membaca bacaan dari teks al-Qur'ân atau sumber lain). Begitu juga, lembaga-lembaga pembelajaran al-Qur'an, tradisi lisan One Day One Juz, (ODOJ). Sejumlah riset memang telah dilakukan terhadap "tafsir Banjar"18 oleh sejumlah penulis, seperti oleh Haman Faizin, ${ }^{19}$ Nor Azizah, ${ }^{20}$ Hanief Monady, ${ }^{21}$ dan Wardani ${ }^{22}$ terhadap penafsiran Djohan Efendi dalam karyanya, Pesan-pesan al-Qur'an, Masyithah Annajah terhadap penafsir Muhammad Ghazali, ${ }^{23}$ Syahruni terhadap penafsiran Ahmad Ghazali, ${ }^{24}$ Nizar Perdana terhadap penafsiran Abdullah Karim, ${ }^{25}$

pengetahuan yang mendalam tentang bahasa Arab (solid background in the Islamic sciences and a thorough knowldge of Arabic), sehingga "sebagian dari tafsir awam tetap sophisticated, sedangkan yang lain (yang tidak memiliki latar belakang kajian keislaman) superfisial dan tidak diterima di kalangan ulama". Lihat Andreas Gorke, "Redefining the Borders of Tafsir: Oral Exegesis, Lay Exegesis and Regional Particularities," Tafsir and Islamic Intellectual History: Exploring the Boundaries of a Genre, 2014, 363-380. Lihat juga Patrick J. D’Silva, "Tafsir and Islamic Intellectual History: Exploring the Boundaries of a Genre Edited by Andreas Görke and Johanna Pink. Qur'anic Studies Series, 12. London: Oxford University Press in association with the Institute of Ismaili Studies, 2014, Religious Studies Review 43, no. 1 (2017): 71-72. Atas dasar ini, tafsir K.H. Husin Kaderi seharusnya tidak digolongkan dalam kategori tafsir awam.

${ }^{17}$ Lihat Wardatun Nadhiroh, Tradisi Kelisanan dan Keaksaraan al-Qur'an di Tanah Banjar (Banjarmasin: Antasari Press, 2018).

${ }^{18}$ Yang penulis maksud dengan istilah ini adalah tafsir yang ditulis oleh penulis yang berasal dari kelahiran Banjar, tafsir urang (orang) Banjar, meskipun penulis sekarang tinggal di tempat lain. Atas dasar ini, karya Djohan Effendi (w. 2017), Pesan-pesan al-Qur an, meski tidak ditulis dengan bahasa Banjar, dikategori sebagai tafsir Banjar. Tentang penulis ini, lihat Ahmad Gaus AF, Sang Pelintas Batas: Biografi Djohan Effendi (Jakarta: ICRP dan Penerbit Buku Kompas, 2009).

${ }^{19}$ Hamam Faizin dan Arsyad Sobby Kesuma, "Pemikiran Tafsir Djohan Effendi," KALAM 11, no. 2 (2017): 456-487.

${ }^{20}$ Noor Azizah, "Djohan Effendi's Method in Formulating the Essence of the Qur'an in His Book Pesan-pesan al-Qur'an Mencoba Mengerti Intisari Kitab Suci," Skripsi S1 Fakultas Ushuluddin dan Humaniora (Banjarmasin: UIN Antasari Banjarmasin, 2014).

${ }^{21}$ Lihat Djohan Effendi, Pesan-Pesan Al-Qur'an: Mencoba Mengerti Intisari Kitab Suci (Jakarta: PT. Serambi ilmu Semesta, 2012). Lihat juga "Pesan-Pesan Alquran: Mencoba Mengerti Intisari Kitab Suci Karya: Djoban Effendi (Studi Kitab Tafsir) - Kumpulan Tulisan Hanief Monady,” diakses 13 September 2018, https://haniefmonady.wordpress.com/2015/11/01/pesan-pesan-alquran-mencoba-mengerti-intisarikitab-suci-karya-djohan-effendi-studi-kitab-tafsir/.

${ }^{22}$ Wardani, Trend Perkembangan Pemikiran Kontemporer, 95-110.

${ }^{23}$ Masyithah Annajah, "Dirâsah 'an Manhaj al-Tafsîr al-Mawdhû'î ind al-Ustâd al-Duktûr Muhammad al-Gazâlî al-Banjarî fî Kutubih," Skripsi S1 (Banjarmasin: Fakultas Ushuluddin dan Humaniora UIN Antasari, 2017).

${ }^{24}$ Syahruni, "Pemikiran Tafsir Ahmad Gazali dalam Karyanya al-Qur`an: Tafsir Ayat-ayat Iptek," Skripsi S1 (Banjarmasin: Fakultas Ushuluddin dan Humaniora UIN Antasari, 2017).

25Nizar Perdana, "Kiprah dan Pemikiran Tafsir Prof. Dr. H. Abdullah Karim, M.Ag.," Skripsi S1 (Banjarmasin: Fakultas Ushuluddin dan Humaniora UIN Antasari, 2016). 
dan Halimatus Sa'diah terhadap Tafsir Juæ` 'Amma karya tim penulis Penerbit Sahabat (Kandangan). ${ }^{26}$

Kajian yang khusus terfokus tentang unsur lokal dalam terjemah al-Qur`an berbahasa Banjar ini dilakukan oleh Saifuddin, Dzikri Nirwana, dan Norhidayat, namun apa yang dimaksud dengan "unsur lokal" di sini dalam pengertian umum sekali, dari asal-usul penerjemah, keragaman terjemah, varian bahasa Banjar yang digunakan, strata sosial kerajaan, aliran (teologi, fiqh, kebudayaan pra-Islam), budaya agraris, siklus kehidupan, budaya gunung dan budaya sungai. Sayangnya, kajian ini hanya sedikit menyoal nilai-nilai moral yang menjadi bagian dari kearifan lokal masyarakat Banjar. Temuan bahwa bahasa Banjar cenderung lebih "egaliter", karena tidak mengenal strata yang terlalu kaku dalam penggunaan bahasa, dibandingkan bahasa Jawa yang diliputi banyak stratifikasi, ${ }^{27}$ tidak sepenuhnya benar, karena kesopanan selalu menghendaki ada stratifikasi penggunaan kosa-kata yang lebih sopan untuk orang yang dihormati. Khalilah Nur Azmy juga meneliti terjemah ini, yaitu dari aspek metode penerjemahan ini. ${ }^{28}$ Namun, penelitian ini sangat terbatas pada hal-hal yang bersifat teknis, seperti pemberian keterangan dalam tanda kurung, keterangan langsung, dan catatan kaki. Metode yang juga dibahas di sini adalah tentang prioritas bahasa yang digunakan (Banjar asli atau tutuk, bahasa Banjar-Melayu, Bahasa Indonesia yang dibanjarisasikan, dan bahasa Indonesia yang diadopsi ke bahasa Banjar.

Terjemah al-Qur'an dalam bahasa Banjar ini adalah bagian dari upaya panjang yang telah dilakukan untuk menghidangkan terjemah al-Qur`an di Indonesia. Upaya itu sebenarnya telah didahului oleh terjemah ke bahasa Indonesia, baik oleh sebagian intelektual Muslim maupun oleh Kementerian Agama RI. Namun, seiring dengan kebutuhan lokal, terjemah al-Qur'an ke bahasa Indonesia dianggap belum mencukupi, karena masyarakat memerlukan bahasa terjemah yang mudah dimengerti dan menyentuh kesadaran dan pengetahuan lokal. Atas dasar ini, ditulislah terjemah al-Qur'an dalam bahasa-bahasa lokal dengan berbagai variasi tampilan dan dengan metode berbeda.

Untuk merespon kebutuhan lokal itu, Kementerian Agama RI juga menerjemahkan al-Qur`an ke berbagai bahasa lokal. Sejak 2011, Puslitbang Lektur, Khazanah Keagamaan, dan Manajemen Organisasi (Puslitbang LKKMO), Badan Litbang dan Diklat Keagamaan Kementerian Agama RI menyelenggarakan penerjemahan al-Qur`an ke bahasa-bahasa daerah dengan berkerjasama dengan perguruan tinggi setempat, baik UIN, IAIN, STAIN, maupun STAIS. Sampai 2016, tercatat terjemah al-Qur`an ke bahasa-bahasa daerah mencapai dua belas: ke bahasa Makassar (Sulawesi Selatan), ke bahasa Kaili (Sulawesi Tengah), ke bahasa Sasak

${ }^{26}$ Sa'diah Halimatus, "Manhaj Tafsîr Tim Sahabat Kandangan (Dirâsah Manhajiyyah fî Tafsîr Juz 'Amma)," Skripsi S1 (Banjarmasin: Fakultas Ushuluddin dan Humaniora UIN Antasari, 2017).

${ }^{27}$ Saifuddin, Dzikri Nirwana, dan Norhidayat, Pengarub Unsur-unsur Budaya Lokal dalam alQur`an dan Terjemahnya Bahasa Banjar (Banjarmasin: Antasari Press, 2018), 169-170.

${ }^{28}$ Khalilah Nur Azmy, "Metode Penerjemahan al-Qur`an dalam Bahasa Banjar (Studi Analisis terhadap al-Qur`an Terjemah Bahasa Banjar)," Skripsi S1 (Banjarmasin: Fakultas Ushuluddin dan Humaniora UIN Antasari, 2018). 
(Nusa Tenggara Barat), ke bahasa Minang (Sumatera Barat), ke bahasa Dayak Kanayatn (Kalimantan Barat), ke bahasa Jawa Banyumasan (Jawa Tengah), ke bahasa Toraja (Sulawesi Selatan)/, ke bahasa Mangondow (Sulawesi Utara), ke bahasa Batak Angkola (Sumatera Utara), ke bahasa Melayu Ambon (Maluku), ke bahasa Bali, dan ke bahasa Banjar (Kalimantan Selatan). ${ }^{29}$ Pada 2018, berhasil disusun terjemah alQur`an bahasa Aceh, Bugis, dan Madura. ${ }^{30}$ Di samping itu, terjemah al-Qur`an juga dilakukan ke bahasa Palembang. ${ }^{31}$ Bahkan, terjemah al-Qur`an bahasa Tegal telah berhasil disusun oleh Ikatan Mahasiswa Tegal IAIN (sekarang: UIN) Walisongo pada $2012 .^{32}$

Penerjemahan al-Qur’an ke bahasa Banjar ini memiliki keunikan yang tidak diungkap oleh para pengkaji terdahulu, baik oleh Saifuddin maupun Khalilah Nur Azmy. Pertama, tidak seperti apa yang diungkap oleh Azmy, persoalan metodologis penafsiran bukan sekadar persoalan teknis, melainkan lebih shopisticated, misalnya tentang bagaimana pergerseran dari tarjamah harfiyyah ke tarjamah tafsiriyyah, dan persoalan tentang muatan budaya di dalamnya. Bahkan, yang lebih unik adalah bahwa bahasa Banjar tidak pernah, sejauh pengetahuan penulis, digunakan secara sempurna dalam tulisan akademis, ${ }^{33}$ sehingga penelusuran terhadap bagaimana para penerjemah

${ }^{29}$ Chairul Fuad Yusuf, "Pengantar", dalam Tim Penerjemah, al-Qur an dan Terjemahnya Babasa Banjar (Jakarta: Puslitbang Lektur dan Khazanah Keagamaan Badan Litbang dan Diklat Kementerian Agama, 2017), vii-viii.

${ }^{30}$ Lihat "Kemenag Kembali Luncurkan Al-Qur`an Terjemah Tiga Bahasa Daerah," diakses 25 Maret 2019, http://m.santrinews.com/Nasional/8764/Kemenag-Kembali-Luncurkan-Al-Qur`anTerjemah-Tiga-Bahasa-Daerah. Lihat juga dalam berita di website UIN Ar-Raniry dengan judul "Kemenag Luncurkan Alquran Terjemah Bahasa Aceh," diakses 25 Maret 2019, http://www.arraniry.ac.id/index.php/id/posts/kemenag-luncurkan-alquran-terjemah-bahasa-aceh. Lihat "Kemenag Mulai Proses Penyusunan Terjemah Al-Quran Berbahasa Madura | Dinas Komunikasi dan Informatika Provinsi Jawa Timur," diakses 25 Maret 2019, http://kominfo.jatimprov.go.id/read/umum/-kemenag-mulai-proses-penyusunan-terjemah-al-quranberbahasa-madura.

${ }^{31}$ Lihat "Subhanallah, Al Quran Terjemahan Berbahasa Palembang Akan Diterbitkan. Baru 12 Juzz Diterjemahkan Sriwijaya Post," diakses 25 Maret 2019, https://palembang.tribunnews.com/2018/02/27/subhanallah-al-quran-terjemahan-berbahasapalembang-akan-diterbitkan-baru-12-juzz-diterjemahkan.

32Lihat "Terjemah Al-Qur'an Bahasa Tegal diluncurkan mahasiswa," Nahimunkar, diakses 25 Maret 2019, https://www.nahimunkar.org/terjemah-al-quran-bahasa-tegal-diluncurkan-mahasiswa/.

${ }^{33}$ Bahasa Banjar hingga kini lebih banyak hanya digunakan dalam penulisan karya-karya sastra, seperti buku-buku pantun, misalnya yang ditulis oleh Maria Roesli, dan dalam penulisan surat-surat kerajaan. Lihat "Mengukur Eksistensi Bahasa Banjar Dari Karya Sastra Hingga Karya Akademik jejakrekam.com," diakses 2 Mei 2020, https://jejakrekam.com/2019/12/28/mengukur-eksistensibahasa-banjar-dari-karya-sastra-hingga-karya-akademik/. Dalam bentuk karya akademik, beberapa kosa-kata bahasa Banjar hanya digunakan sebagai kosa-kata serapan dalam tulisan yang secara keseluruhan berbahasa Melayu, misalnya, Sabîl al-Mubtadîn karya Syekh Muhammad Arsyad al-Banjarî. Dalam karya ini, misalnya, digunakan kosa-kata bahasa Banjar, semisal: rupui (hancur menjadi bagianbagian kecil), tukul (palu), sadur (seng), guliga (sendawa), tambuni (plasenta yang sudah dikeluarkan dari perut ibu hamil), salumu atau salumur (kulit tipis binatang yang terlepas ketika pergantian kulit), balat (batas), susudu (centong), dan haduk (ijuk). Lihat Ahmad Rijali, "Kandungan Budaya Bahasa Melayu Banjar dalam Kitab Sabîl al-Muhtadîn Karya Syekh Muhammad Arsyad al-Banjarî," Laporan Hasil Penelitian (Banjarmasin: Lembaga Penelitian dan Pengabdian kepada Masyarakat, 2015), 33-38.

Khazanah, Vol. 18 (1), 2020 
mencoba memahami bahasa Arab untuk diterjemahkan ke bahasa lokal yang identik dengan bahasa lisan itu. Kedua, bahasa Banjar adalah varian dari bahasa Melayu yang kompleks, di samping memiliki kesamaan dengan bahasa serumpun di beberapa wilayah yang menunjukkan beberapa kesamaan tradisi, juga tak pelak memiliki keunikan masing-masing wilayah di mana bahasa ini dituturkan. Bahasa Banjar sebenarnya tidak hanya dituturkan oleh warga Kalimantan Selatan, melainkan oleh beberapa penutur di beberapa wilayah lain di Kalimantan dan Riau (Indragiri Hilir). Bahasa ini merupakan bahasa sastra lisan dengan dua dialek, yaitu dialek Banjar Kuala dan Banjar Hulu. Sebelum dikenalnya bahasa Indonesia sebagai bahasa resmi dalam tulisan, orang Banjar menggunakan bahasa Melayu Banjar dengan menggunakan aksara Arab, seperti tampak dalam Syair Siti Zubaidah, Syair Tajul Muluk, Syair Burung Karuang, Hikayat Banjar, dan Tutur Candi. ${ }^{34}$

\section{Metode}

Tulisan ini mengkaji terjemah al-Qur`an ke bahasa Banjar ini dari dua aspek. Pertama, bentuk kearifan yang terkandung dalam terjemah al-Qurân dalam bahasa Banjar. Kedua, dimensi partikularitas dan universalitas dari kearifan lokal yang termuat di dalamnya. Kearifan lokal dimaksud adalah nilai-nilai moral yang dijunjung oleh kultur setempat. Pendekatan yang diterapkan adalah hermeneutis-filosofis, yaitu mengungkapkan bahwa masyarakat Banjar melalui penggunaan kosa-kata tertentu memberikan makna secara moral-filosofis, terkait hubungannya dengan sesama dan mengekspresikan rasa takzim kepada Tuhan. Teori yang diterapkan adalah distingsi dalam filsafat etika antara yang partikular dan yang universal.

Kajian ini menerapkan studi kepustakaan (library research) dengan sumber primer al-Quran dan Terjemabnya Babasa Banjar yang diterbitkan oleh Puslitbang Lektur Keagamaan Kementerian Agama RI pada tahun 2017 dan dilengkapi dengan sumber-sumber sekunder berupa tulisan-tulisan yang mengulas tentang karya ini, seperti karya Saifuddin dan Khalilah Nur Azmy, sebagaimana disebutkan.

\section{Pembahasan}

\section{Bentuk Kearifan Lokal Banjar dalam Terjemah al-Qur`an Berbahasa Banjar}

Penerjemahan sebagai upaya memahami kandungan al-Qur`an, tidak semata pengalihan bahasa, tentu menyelipikan makna-makna, persepsi, atau pemahaman penerjemah dengan menuangkan ke dalam bahasa lain yang tentu sering memuat

${ }^{34}$ Lihat "Bahasa Banjar" dalam Wikipedia bahasa Indonesia, ensiklopedia bebas, diakses 26 Mei 2020, https://id.m.wikipedia.org/wiki/Bahasa_Banjar_(26). 
kearifan lokal. Tim penerjemah terkadang memilih tarjamah tafsiriyyah, ${ }^{35}$ dibandingkan tarjamah harfiyyah, ${ }^{36}$ bahkan dengan muatan kearifan lokal (local wisdom).

1. Penyebutan kata ganti untuk Tuhan

Seperti umumnya dalam bahasa lain, bahasa Banjar juga mengenal tingkatan penggunaan bahasa, yaitu bahasa kasar dan bahasa halus (sopan).

\begin{tabular}{lll}
\hline \multicolumn{1}{c}{ Kata Ganti } & \multicolumn{1}{c}{ Kasar/ Setara } & \multicolumn{1}{c}{ Halus/ Sopan } \\
\hline Aku, saya & Aku & Ulun \\
\hline Kami & Kami & Kami \\
\hline Kita & Kita & Kita \\
\hline Kamu, engkau & Ikam & Pian, sampian, andika \\
\hline Kalian & Buban ikam & Buban (pian, sampian, andika) \\
\hline Dia & Inya & Sidin \\
\hline Mereka & Bubannya & Buban sidin \\
\hline
\end{tabular}

Tabel 1. Ungkapan Bahasa Banjar

Dalam hubungannya dengan Tuhan, dalam al-Qur an dan Terjemahnya Babasa Banjar digunakan kata ganti yang halus atau sopan, yaitu ulun (menyebut hamba ketika berhubungan dengan Tuhan, seperti dalam doa), Pian atau Sampian, dan Sidin, seperti dalam terjemah berikut: "Wan Sampian haja kami manyambah wa lawan Sampian haja kami mainta partulungan" (Q.s. al-Fâtihah: 5). ${ }^{37}$

Sebagaimana umumnya dalam kultur lain, dalam budaya Banjar juga, tata krama dalam berbicara dengan orang yang lebih atau orang dihormati mengharuskan penggunaan ungkapan yang halus. Jika seseorang tidak menggunakan bahasa halus terhadap orang tua, ia dianggap "tidak tahu tata krama" (kada tabu dibasa, kada tabu diadat, kada baadat). Berbeda dengan penggunaan bahasa Jawa dalam terjemah alQur`an, di mana istilah-istilah yang umumnya digunakan untuk hubungan manusia, seperti kata "Pangeran", digunakan untuk menyebut Tuhan, ${ }^{38}$ sejauh pengetahuan penulis, dalam bahasa Banjar belum pernah istilah serupa, termasuk kata ganti, diterapkan pada Tuhan. Hal ini mungkin disebabkan oleh dua faktor. Pertama, bahasa Banjar, berbeda dengan bahasa Jawa, identik dengan bahasa percakapan, dibandingkan sebagai bahasa yang digunakan untuk tulisan, kecuali dalam perkembangan belakang, seperti rubrik "Palui" (nama imajiner, sebuah rubrik yang

${ }^{35}$ Tarjamah tafsiriyyah adalah "terjemah tanpa memperhatikan kesesuaiannya dengan susunan dan urutan semula, dan yang dipentingkan adalah gambaran makna dan tujuannya secara sempurna". Muhammad 'Abd al-'Azhîm al-Zarqânî, Manâhil al-Irfân fi 'Ulûm al-Qur ân, vol. 2 (Beirut: Dâr al-Fikr, t.th), 111.

${ }^{36}$ Tarjamah harfiyyah adalah terjemah secara harpiah atau literal, kata perkata, tanpa memperhatikan kandungan maknanya secara esensial, melainkan hanya kesesuaian dengan susunan kalimat. al-Zarqânî, 2:113-114.

${ }^{37}$ Tim Penerjemah, al-Qur'an dan Terjemahnya Babasa Banjar, 1.

${ }^{38}$ Imam Muhsin, Al-Qur'an dan budaya Jawa dalam tafsir al-Huda karya Bakri Syabid (Yogyakarta: eLSAQ Press, 2013), 92-93. 
berisi cerita-cerita fiksi jenaka, sebagai media hiburan rakyat) ${ }^{39}$ di Surat Kabar Harian Banjarmasin Post. Karena identik dengan bahasa percakapan, bahasa Banjar tidak mengekspresikan sejauh bahasa Jawa. Sebagai bahasa percakapan, bahasa Banjar lebih banyak digunakan untuk mendeskripsikan aktivitas keseharian, namun tidak mendeskripsikan hal-hal yang abstrak. Sebagai gantinya, pada zaman dahulu masyarakat Banjar menggunakan bahasa Melayu dengan aksara Arab (pegon) untuk menulis karya-karya keislaman, seperti tampak misalnya pada Sabîl al-Mubtadin karya Syekh Muhammad Arsyad al-Banjarî dan sekarang dengan bahasa Indonesia, seperti Manganal al-Asmâ al- $\underline{H} u s n \hat{a}$ karya KH. Muhammad Bakhît. Bahasa Banjar, sebagaimana dikemukakan, hanya digunakan sebagai bahasa serapan pada bahasa Melayu.

Kedua, dari konteks historis-sosiologis, masyarakat Banjar mengalami keadaan traumatik secara teologis jika melekatkan sebutan-sebutan yang berlaku pada manusia (raja, pangeran, atau bangsawan) kepada Tuhan, seperti halnya "Gusti", yaitu istilah yang di kalangan masyarakat Banjar digunakan untuk menyebut keturunan bangsawan. ${ }^{40}$ Penulisan kitab Tuhfat al-Râghibin oleh Muhammad Arsyad al-Banjarî, di mana di dalamnya ia melakukan kritik pemurnian tawhîd dari paham-paham teologis yang hidup di masanya dan yang hidup sebelumnya di dunia Islam, seperti antropomorphisme (tajsim), membuktikan bahwa pelekatan sebutan-sebutan itu tampak dikhawatirkan akan memunculkan sinkretisme dalam beragama, atau antropomorphisme dalam bertaw $\underline{h} \hat{\imath} d^{41}$

Dalam kultur Banjar, penghormatan terhadap orang tua dan orang yang dihormati sangat ditekankan, antara lain, terlihat dari sebutan "tutuba" (dari kata

${ }^{39}$ Orang Banjar memiliki selera humor yang cukup tinggi. Di samping cerita-cerita yang hidup di obrolan-obrolan masyarakat Banjar, yang kemudian dimasukkan ke rubrik "Palui", bersama cerita kreasi redaksi, juga dikenal model bermain kata secara jenaka untuk tebakan atau untuk menjadikan lawan bicara salah persepsi, yaitu "mahalabiu”. Ungkapan "mahalabiu” berasal dari "Halabiu”, yaitu suatu daerah di Kabupaten Hulu Sungai Utara, Kalimantan Selatan. Kata "Halabiu” sebenarnya bentuk pengucapan yang berkembang di lisan sebagian masyarakat Banjar untuk sebutan yang sesungguhnya, "Alabio", seperti "Hamuntai" untuk "Amuntai" (ibukota Kabupaten Hulu Sungai Utara). Kemudian, kata "Halabiu" dibubuhi awal ma- (me-), sehingga menjadi "mahalabiu", seperti mirip dengan kata "mendunia" dalam bahasa Indonesia. Jadi, "mahalabiu" secara literal bermakna "seperti berada di, atau mengikuti cara orang Halabiu (Alabio)". Pendapat lain menyebutkan bahwa kata ini terbentuk dari kata "mahala" (tanggung) dan "biu" (singkatan dari Alabio). Tradisi sastra lisan ini terkait dengan peran orang Alabio yang dikenal sebagai sub-etnik yang gemar membuat cerita-cerita lucu, sedangkan orangorang non-Alabio hanya sebagai "penyambung lisan". Rustam Effendi, "Eksistensi Sastra Lisan Mahalabiu bagi Masyarakat Banjar Kalimantan Selatan,” LITERA 11, no. 2 (2012): 299. Lihat juga "Mahalabiu," diakses 3 Mei 2020, https://id.m.wikipedia.org/wiki/Mahalabiu.

${ }^{40}$ Lihat Helius Sjamsuddin, Pegustian dan Temenggung: akar sosial, politik, etnis, dan dinasti perlawanan di Kalimantan Selatan dan Kalimantan Tengah, 1859-1906 (Balai Pustaka, 2001), 236-242.

${ }^{41}$ Lihat Muhammad Arsyad al-Banjarî, Tuhfat al-Râghibin. Di antara kepercayaan lokal yang dianggap menyimpang adalah manyanggar banua dan mambuang pasilib (membuang sial). Tentang hal ini, lihat M. Asywadie Syukur, "Risalah Tuhfah al-Râghibîn", dalam Khazanah Intelektual Islam Ulama Banjar, ed. Masdari dan Zulfa Jamalie (Banjarmasin: Pusat Pengkajian Islam Kalimantan, 2003), 13-32. Lihat juga Noorhaidi, "Muhammad Arshad al-Banjari (1710-1812) and the Discourse of Islamization in the Banjar Sultanate," Tesis S2 (Leiden: Universitas Leiden, 1999). 
“tuha" yang bermakna tua, maksudnya: orang tua atau dipandang terhormat). Bahkan, penghormatan terhadap "tutuha" terwujud dalam penghormatan terhadap leluhur yang meninggal. Tradisi kematian dengan membaca bacaan keagamaan pada hari ke1-7, 25, 40, 100 hingga setahun (bawlan) tidak bisa hanya dilihat sebagai "kewajiban" agama bagi kalangan "tua", seperti kalangan Nahdiyyin, melainkan juga sebagai bentuk penghormatan dan tanda bakti generasi muda kepada orang tua dan leluhur. ${ }^{42}$

Kandungan ide tentang penghormatan terhadap orang tua tersebut kini teraplikasi juga terhadap Tuhan sebagai dzat yang bahkan tidak hanya sekadar dihormati, melainkan harus disembah dan diagungkan. Dalam proses penerjemahan al-Qur`an ke bahasa Banjar seperti ini, memang muncul kritik, karena terkesan akan menimbulkan paham antropomorphisme. Dalam kultur Banjar, pemilihan kata ganti "pian" dan "sidin" tersebut atas dasar ketuaan dan kehormatan, sedangkan kepada Tuhan, kini atas dasar $t a^{\prime}{ }^{\prime} h \hat{\imath} m$ (pengagungan), penghambaan, dan penyembahan.

\section{Larangan Berpecah-belah}

Kearifan lokal ini bisa ditarik dari ungkapan "jangan bacakup" (jangan berpecah-belah), sebagaimana tampak dari terjemah berikut:

"Sidin sudah manyariatakan (manyurub) gasan bubanmu sual agama napa nang sudah diwasiatakan-Nya lawan Nub wan napa nang sudah Kami wabyuakan lawan ikam wan napa nang sudab Kami wasiatakan lawan Ibrâbim, Mûsâ, dan Isâ, bahawa diriakan ba agama, wan janganlah buban ikam bacakut sual nitu..." (Q.s. al-Syûrâ 42: 13). ${ }^{43}$

Apa perbedaan mendasar antara "jangan berpecah-belab" dan "jangan bacakul" sebagai hasil terjemah lâ tatafarraqu? Ungkapan "lâ tatafarraqu’" memiliki makna asalnya bercerai-berai menjadi sekte-sekte (firqah). Jika ungkapan ini diterjemahkan dengan "pacah balab", pesan intinya tidak bisa ditransferkan seperti halnya "pecahbelah" dalam bahasa Indonesia, karena "pacah balah" dalam komunitas Banjar berkonotasi fisik material. Sebagai padanannya, kata tersebut diganti dengan kata "bacakup". Secara kebahasaan, kata ini berasal dari kata "cakup" yang bermakna "pegang", kemudian mengalami tambahan awal ba (ber), sehingga bacakut bermakna "berpegang", seperti dikatakan "bacakut di tall" (berpegang di tali)." Kata ini umumnya di kalangan masyarakat Banjar memiliki konotasi "berpegangan erat". Karena penekanan makna ini, kata ini kemudian diartikan secara konotatif sebagai "berkelahi”, misalnya: "jangan bacakue" (jangan berkelahi), ${ }^{45}$ karena berpegang erat tersebut dikonotasikan dengan memegang erat pakaian orang lain, seperti pada kerah

42Pelanggaran terhadap kewajiban orang masih hidup kepada keluarganya yang telah meninggal menyebabkan kejadian mistik di luar nalar, seperti kerasukan roh orang telah meninggal (kapidaraan), menyebabkan celaka secara tiba-tiba (kapubunan). Lihat tradisi peringatan atau ritual persembahan terkait dengan kematian, dalam Alfani Daud, Islam dan masyarakat Banjar: Deskripsi dan Analisa Kebudayaan Banjar (Jakarta: RajaGrafindo Persada, 1997), 305-13.

${ }^{43}$ Tim Penerjemah, al-Qur`an dan Terjemahnya Bahasa Banjar, 673.

${ }^{44}$ Departemen Pendidikan Nasional Pusat Bahasa, "Kamus Bahasa Banjar Dialek Hulu Indonesia," Banjarmasin: Balai Bahasa, 2008, 33.

${ }^{45}$ Bahasa, 33. 
baju, dalam berkelahi. Bacakut sebagai berkelahi sudah umum digunakan secara konotatif dalam bahasa Banjar. Kata itu kemudian dilekatkan pada kata lain, seperti "bacakut papadaan" (berkelahi sesama kerabat). "Jangan bacakut papadaan" sudah menjadi peribahasa yang menjadi bagian dari kearifan lokal Banjar. ${ }^{46}$

Kultur Banjar, di mana ikatan kekerabatan sangat kuat seperti tampak dalam ungkapan "bububan" (kelompok secara keturunan, etnis, atau ikatan lain), menganggap "bacakut papadanan" sebagai perbuatan yang sangat dicela, karena bagaimana pun perbedaan atau konflik yang terjadi, seharusnya menurut adat berdamai di kalangan masyarakat Banjar, bisa diselesaikan atas dasar kekerabatan, sehingga jika antarsesama kerabat masih juga terjadi konflik, maka hal itu dianggap sangat tercela. Konstruksi moral ini tercermin dalam ungkapan pribahasa "jangan bacakut papadaan" (jangan berkelahi sesama kerabat!). Peribahasa ini tercantum dalam sebuah pantun yang digubah oleh Syamsiar Seman (w. 2013): "Tulak mamulut baduduan. Imbah bulik di wayah sanja. Jangan bacakut papadaan. Hual sadikit baakuran haja" (Pergi menangkap burung dengan pulut [lem penjebak] berduaan. Setelah pulang di waktu senja. Jangan bertengkar dengan kerabat. Perselisihan sedikit bermaafan saja). ${ }^{47}$ Pribahasa ini memiliki nilai moral berikut. Pertama, "papadaan", sesama kerabat atau sahabat adalah sesuatu yang harus dijaga, tidak boleh hubungannya sampai retak. Kedua, menghormati sesama untuk kepentingan perdamaian adalah lebih baik daripada berseteru. ${ }^{48}$ Karena kandungannya berupa nasehat, meski dituangkan dalam bentuk pribahasa dan pantun, kearifan lokal disebut juga dengan papadah atau papadaban (nasihat). Nilai kekerabatan ini pernah dijadikan dasar untuk menggalang

\footnotetext{
46 Lihat Arsyad Indradi, "Khazanah Makna Kata Bahasa Banjar: Peribahasa dalam Bahasa Banjar," dalam Khazanah Makna Kata Bahasa Banjar (blog), 2 Agustus 2008, http://khazmakata.blogspot.com/2008/08/peribahasa-dalam-bahasa-banjar.html.

${ }^{47}$ Yuliati Puspita Sari, "Kecerdasan Emosional Orang Banjar dalam Pantun Banjar," Sawerigading 20, no. 1 (2015): 154. Kata “mamulue" berasal dari kata "pulue" yang bermakna "perekat dari getah yang disadap dari pohon karet atau pohon tarap (sejenis nangka dengan bentuk bulat dan dengan ukuran lebih kecil) yang tumbuh di pedalaman. Pulut diolah sedemikian rupa dengan dilekatkan pada bilah-bilah bambu, sehingga bisa digunakan untuk menjebak burung. "Mamulue" adalah menangkap burung dengan perekat tersebut. Tradisi berburu ini umumnya dilakukan oleh masyarakat perdesaan di persawahan.

48Rezqan Noor Farid, "Wisdom Values in the Banjarese Proverbs," PAROLE: Journal of Linguistics and Education 5, no. 1 (2015): 56. Selain membahas nilai moral di balik pribahasa Banjar, artikel ini juga membandingkan antara kearifan lokal Banjar ini dengan ajaran al-Qur’an. Komparasi ini mengarah pada kesimpulan bahwa kultur Banjar cukup agamis (Qur` ni). Artikel ini menjadi penyeimbang bagi kajian Alfani Daud, Islam dan Masyarakat Banjar, yang dengan perspektif antropologi klasiknya melihat budaya Banjar lebih dari sisi magik dan kepercayaan lokal yang jauh dari ajaran alQur’ân, atau tidak cukup lekat dengan ajaran kitab sucinya. Kajian Ahmad Rafiq tentang berbagai tradisi al-Qur`an yang hidup di masyarakat Banjar hampir searah dengan artikel ini, yaitu bahwa Islam di kawasan di luar Timur Tengah sebagai, katakanlah, "Islam pinggiran"-jika dilihat dari Timur Tengah sebagai "pusat, sentral”- dinilai masih cukup lekat dengan kitab suci al-Qur'an. "Orang Banjar umumnya mengutamakan resepsi fungsional dengan menekankan fungsi al-Qur’an untuk diterapkan. Akan tetapi, itu tidak berarti bahwa resepsi fungsional itu secara keseluruhan pasti terlepas dari tradisi tafsirnya". Lihat Ahmad Rafiq, "The Reception of the Qur an in Indonesia: A Case Study of the Place of the Qur'an in a Non-Arabic Speaking Community," Disertasi Ph.D (Philadelphia: Temple University, 2014), v.
} 
kekuatan melawan penjajah Belanda dan juga masih berlaku hingga kini di kalangan masyarakat Banjar. ${ }^{49}$ Konon, pada masa penjajahan Belanda, Pangeran Antasari (1797-1862 M) berwasiat kepada masyarakat Banjar:

"Haram manyarah. Waja sampai ka puting. Lamun tanah banyu kita kahada handak dilincai urang, jangan bacakut papadaan kita. Lamun handak tulak manyarang Walanda, baikat hati di tali sindad. Jangan sampai mati parahatan bukah. Matilah kita di jalan Allah. Siapa babaik-baik lawan Walanda, tujub turunan kada aku sapa. Lamun kita sudah sapakat, handak mabinyik Walanda, jangan Walanda dibari muha. Badalas pagat urat gulu, lamun manyarah kahada. Haram dijamah Walanda. Haram diriku dipanjara. Haram negri dijajah. Haram manyarah. Waja sampai ka puting". ${ }^{50}$

(Haram menyerah. Baja sampai ke ujung [senjata tajam]. Jika tidak ingin Tanah Air kita diinjak-injak orang, jangan berseteru sesama saudara [papadaan] kita. Jika ingin berangkat menyerang Belanda, ikatkan tekad hati ke tali yang terbuhul kuat. Jangan sampai mati ketika lari. Matilah kita di jalan Allah. Siapa yang menunjukkan sikap baik kepada Belanda, tujuh keturunan tidak aku sapa. Jika kita sudah sepakat ingin menindih kuat-kuat terhadap Belanda, jangan Belanda diberi kesempatan. Meski sampai putus urat leher, tidak akan menyerah. Haram dijamah Belanda. Haram diriku dipenjara. Haram negeri dijajah. Haram menyerah. Baja sampai ke ujung.)

Kata "papadaan" (kerabat) mengandung pengertian "kada urang" (bukan orang lain, melainkan dari kerabat sendiri). Larangan berkonflik antarsesama kerabat mengandung pesan moral agar setiap persoalan yang terkait dengan kerabat diselesaikan secara kekeluargaan dengan saling memahami dan menghargai orang lain sebagai suatu ikatan kekeluargaan. Atas dasar semangat kekeluargaan ini, permasalahan yang muncul diselesaikan dengan kepala dingin, dengan musyawarah, dan dengan kesediaan menerima keadaan bagaimanapun. ${ }^{51}$ Ungkapan "jangan berpecah-belah" hanya memuat ujaran larangan, sedangkan ungkapan "jangan bacakue' dalam kultur Banjar mengandung pesan makna moral yang lebih dalam yang berakar dari budaya kekerabatan yang kuat.

Yang dimaksud dengan papadaan (kekerabatan) adalah hubungan sesama, baik dalam hubungan darah atau kedekatan relasi dalam bentuk pertemanan. Papadaan yang diikat oleh kesamaan, baik dalam hubungan darah, kesamaan asal daerah (banua), tampak berdimensi eksklusif, karena akan cenderungan menjadi solidaritas kelompok (fanatisme). Namun, larangan berkonflik dengan sesama kerabat itu juga mengandung ajaran moral yang berlaku universal, yaitu tentang pengendalian diri. ${ }^{52}$ Akan tetapi, di sisi lain, konsep etika ini juga harus dipahami tidak terpisah dari konsep etika Banjar yang lain, misalnya tentang tradisi mencari saudara angkat

\footnotetext{
${ }^{49}$ Agus Yulianto, "Nilai-nilai Luhur Budaya dalam Papadah Banjar di Kalimantan Selatan," Kibas Cenderawasib 15, no. 2 (2018): 197.

${ }^{50}$ Berkatullah Amin, "Pendekatan Konseling Eksistensi Humanistik berbasis nilai Budaya Banjar 'Wasaka' dalam membentuk karakter siswa di Banjarmasin," dalam Prosiding Seminar Nasional Bimbingan dan Konseling, vol. 2, 2018, 93-94.

51Zulkifli, "Makna Ungkapan Tradisional Daerah Banjar," diakses 25 Mei 2020, https://banuahujungtanah.wordpress.com/2010/05/19/ungkapan-tradisional-orang-banjar/.

52Sumasno Hadi, Etika Banjar (Banjarmasin: Lambung Mangkurat University Press, 2017), 60-61.
} 
(dangsanak angkat) dan mencari orang tua angkat (kuitan angkat) sebagai perluasan kekerabatan itu dan tradisi berdamai (adat badamai) di kalangan masyarakat Banjar. Dalam tradisi Banjar, ketika seseorang datang atau migrasi ke suatu daerah untuk waktu yang cukup lama (madam), ia mencari saudara dan orang tua angkat, sebagai perlindungan diri dari tekanan-tekanan di tempat baru. Tradisi ini tidak hanya bermakna praktis, melainkan bermakna sebagai perluasan kekerabatan. Tradisi ini juga bisa terjadi secara insidental (tidak direncanakan sejak awal), yaitu ketika seorang bersuku Banjar menghadapi sengketa di luar daerah tempat tinggalnya, baik masih di ruang lingkup tanah Banjar atau di luarnya, ia melakukan proses berdamai dengan mengangkat orang lain yang meski bukan dari pihak keluarganya dalam hubungan darah. ${ }^{53}$

Tradisi ini tidak bisa dipahami sebagai strategi pragmatis dalam berdamai, agar proses berdamai dilakukan atas dasar atas kekeluargaan, melainkan juga sebagai upaya seorang Banjar untuk meluaskan kekerabatan, karena pasca-perdamaian itu, ia tetap merasa terikat dengan persaudaraan ini. Semangat kekerabatan, terutama di daerah pelosok pedalaman, di mana kultur tetap terjaga, sengketa sering bisa diselesaikan dengan cara kekeluargaan seperti ini. Dengan begitu, pihak-pihak bersengketa memutuskan perkara dengan solusi yang seimbang, tidak cenderung memberatkan salah satu di antara dua pihak. Peribahasa Banjar mengatakan "kuduk kada mati, ular kada kanyang" (kodok tidak mati, ular tidak kenyang) mengandung pengertian bahwa solusi yang diambil harus secara adil, kekeluargaan, dan tidak cenderung hanya memberatkan salah satu pihak. ${ }^{54}$ Dengan kearifan seperti, suku Banjar mampu beradaptasi ketika bermigrasi ke daerah-derah perantauan dan membaur dengan suku-suku lain, baik di Pulau Jawa, Sumatera, maupun di luar negeri, seperti di Malaysia. ${ }^{55}$

3. "Banua" sebagai terjemah dari kata "qaryah" (desa), "al-ardb" (bumi),

Kata "banua" yang digunakan dalam al-Qur'an dan Terjemahnya Babasa Banjar sebenarnya adalah terjemah kata "negeri" yang dalam al-Qur'an sendiri disebut dalam istilah berbeda: "qaryab" (desa, kampung, atau tempat tinggal), "ardb" (tanah,

\footnotetext{
53Sulaiman Tripa, Peradilan Gampong (Banda Aceh: Bandar Publishing, 2019), 64.

${ }^{54}$ Iman Budhi Santosa, Kumpulan peribahasa Indonesia dari Aceh sampai Papua: untuk SD, SMP, SMA \& umum (Jakarta: Kawahmedia, 2009), 64.

${ }^{55}$ Lihat Taufik Arbain, Strategi Adaptasi Migran Banjar (Yogyakarta: LKIS, 2009). Lihat juga Wardani, "Madam Ka Banua Urang: Beberapa Catatan Awal tentang Migrasi Suku Banjar, Proses, dan Penyebarannya". Kandil, Edisi 14, Tahun V, Kandil 14 (Oktober 2007): 51-75. Lihat juga nur Indriyana, "Diaspora Suku Banjar di Tanjung Jabung Barat (Studi Kasus di Kuala Tungkal 1905-1945)," Skripsi S1 (Jambi: Universitas Jambi, 2017). Lihat Arif Rahman Hakim, "Urang Banjar Asli, Urang Banjar Keturunan dan Jarwo," diakses 17 April 2020, https://idr.uinantasari.ac.id/6268/1/Urang\%20Banjar\%20Asli\%2C\%20Urang\%20Banjar\%20Keturunan $\% 20 \mathrm{dan} \% 2$ 0Jarwo.pdf.
}

${ }^{56}$ Lihat, misalnya, Q.s. al-Zukhruf: 23. 
bumi), ${ }^{57}$ Kata "ardh" yang tanpa disandarkan ke hal lain tampaknya lebih tepat diterjemahkan dengan "bumi" atau "daerah" atau "wilayah" secara luas seperti kata "ardhan". ${ }^{58}$ Sedangkan, kata "ardh" yang disandarkan ke kata ganti (kecuali ardh $\hat{\imath}$ "bumi-Ku", milik Tuhan), seperti "ardhinâ", "ardhikum", dan "ardhahum" berkonotasi sebagai kampung halaman, tanah air, atau tempat asal (bomeland) atau "banua" dalam bahasa Banjar.

Dari sejarahnya, istilah "banua" merupakan sebutan untuk sebuah wilayah yang sangat luas yang terdiri dari beberapa buah anak kampung di Kalimantan Selatan pada masa kesultanan Banjar dan masa penjajahan Belanda. Di setiap banua, terdapat suatu sistem kemasyarakatan, yaitu "Sasangga Banua". Banua setara dengan kampung besar yang biasanya disebut di beberapa daerah dengan istilah "negeri" (distrik, lalawangan, watek). ${ }^{60}$ Di Kalimantan Selatan, dikenal sebutan "banua anam", yaitu wilayah enam kabupaten di Banjar Hulu yang meliputi Kabupaten Tapin, Kabupaten Hulu Sungai Selatan, Kabupaten Hulu Sungai Tengah, Hulu Sungai Utara, Kabupaten Balangan, dan Kabupaten Tabalong. Jadi, banua di sini sama dengan kabupaten. Selanjutnya, gabungan dari beberapa banua membentuk sebuah distrik yang disebut "lalawangan" yang dipimpin oleh seorang Kiai Demang, atau disebut "kademangan". Sebagai kepala kedemangan, seorang demang dipimpin oleh atasan yang disebut adipati atau patih/ wedana bangsa Belanda yang menguasai sebuah onderafdeling (setingkat kawedanan atau kepatihan). Distrik ini lebih luas daripada kecamatan (onderdistrik), tapi lebih sempit daripada onderafdeling (kepatihan). Yang dimaksud "banua" sekarang ada yang merupakan desa, dan ada yang kemudian berkembang menjadi kecamatan (onderdistrik). Sebagai contoh, "Lalawangan Banua Ampat" (Distrik Benua Empat) adalah gabungan empat banua, yaitu Banua Padang (sekarang: Kecamatan Tapin Utara), Banua Halat (sekarang: Kecamatan Bungur, Tapin), Banua Parigi (sekarang: sebagian daerah Kecamatan Bakarangan, Tapin), dan Banua Gadung (sekarang: sebagian daerah Kecamatan Bakarangan, Tapin). ${ }^{61}$

Kata "banua" tidak hanya menunjukkan wilayah, daerah, atau tempat tinggal, melainkan lebih dari itu, sebagai kosa-kata yang berkonotasi sebagai "hubungan primordial". Seorang yang berasal dari suku Banjar ketika berada di mana saja selalu memiliki keterikatan dengan "banua" sebagai tempat asalnya. Hubungan atau keterikatan secara psikologis itu menjadikan seseorang bersuku Banjar mengidentifikasi dirinya dengan segala sesuatu yang berkaitan dengan tempat kelahiran, baik pakaian, tradisi, maupun tingkah laku. Sebagai salah satu bukti bahwa kata "banua" bermuatan ikatan primordial tersebut adalah bahwa bahasa yang digunakan di beberapa wilayah di Kabupaten Berau, khususnya di Kecamatan

${ }^{57}$ Lihat, misalnya, Q.s. Yûsuf: 9; Ibrâhim: 13; Thâhâ: 57; al-Qashash: 57. Sebagian dari kata "ardh" masih diterjemahkan secara literal, seperti dalam Q.s. al-Ahzâb: 27 ("tanah"), atau diterjemah dengan "kampung” yang lebih dekat dengan desa (misalnya dalam Q.s. al-A'râf: 110)

${ }^{58}$ Q.s. al-Ahzâb: 27.

${ }^{59}$ Q.s. al-'Ankabût: 56.

60"Banua-Wikipedia bahasa Indonesia, ensiklopedia bebas," diakses 26 Mei 2018, https://id.m.wikipedia.org/wiki/Banua.

${ }^{61}$ Ibid. 
Gunung Tabur, Sambaliung, dan Tanjung Redep disebut dengan bahasa Banua. Bahasa tersebut adalah bahasa suku asli Banua. Namun, bahasa tersebut dari kosakatanya sebagian merupakan kosa-kata bahasa Banjar, seperti "urang" (orang), "kalamian" atau "karamian" (sore, mirip dengan kosa-kata Banjar, "kamarian"), "sagatil" (sedikit sekali), "sudu" (sendok; dalam bahasa Banjar "susudu", alat untuk mengambil nasi dengan ukuran lebih besar daripada sendok), "ranggit" (lebah kecil seukuran nyamuk, rangit), dan "sarubit" (sedikit atau sesobek/ satu sobekan, bahasa Banjar: saribit). ${ }^{62}$ Adanya kesamaan antara bahasa Banua dengan bahasa Banjar menjadi bukti adanya keterpengaruhan bahasa ini dengan bahasa Banjar, atau setidaknya bahasa Melayu yang juga digunakan di Banjar. ${ }^{63}$ Yang sesungguhnya menjadi fokus di sini adalah bahwa bahasa asal disebut sebagai bahasa "banua" karena ikatan primordial.

Menurut J. S. Krom Kontler, Suku Banua berasal dari keturunan Melayu yang membuat pemukiman (koloni) pada masa lampau. Sedangkan, menurut penelitian dr. Muhammad Ramli, seorang dokter yang bertugas di daerah itu, dengan metode bloedgroepbepaling (penentuan golong darah), suku Banua merupakan keturunan Deutro Malay (Melayu muda Sumatera). Hal itu mungkin karena terjadinya percampuran antarsuku melalui perkawinan. Akan tetapi, jelas bahwa suku ini berasal dari suku Melayu. ${ }^{64}$

"Banua" sebagai tanah air (bomeland) tidak hanya menunjukkan wilayah, melainkan lebih dari itu, merupakan suatu bentuk ikatan emosional bagi setiap warga Banjar tentang penting kembali ke asal kelahirannya, ke kebudayaannya, dan identitasnya. Istilah itu lebih merupakan pengikat secara primordial semua warganya, baik ketika berada di Banjar maupun di luar. Oleh karena itu, ketika kata "ardh" atau "qaryah" diterjemahkan dengan "banua", konotasi yang dimunculkan oleh kata tersebut adalah ikatan primordial tersebut, rasa bahasa yang tidak terkandung dalam kata "negeri". ${ }^{5}$ Kata "banua" menjadi pengingat bagi warga suku Banjar di mana saja mereka berada dan menjadi pendorong bagi mereka untuk memperbarui identitas mereka, sekalipun di tempat perantauan, ketika mereka berdiaspora di tengah wargawarga suku lain.

Dalam al-Qur'an sendiri, pengertian tentang adanya ikatan primordial tersebut juga muncul, misalnya, dalam Q.s. Ibrâhim: 13. Dalam ayat, disebutkan "orang-orang kafir berkata kepada rasul-rasul yang diutus kepada mereka, "Kami

62Jhonny Ingglis, “40 Kosa Kata Bahasa Banua Lengkap dan Artinya,” diakses 26 Mei 2018, https://www. tamanbahasa.com/40-kosa-kata-bahasa-banua-lengkap-dan-artinya-513. Lihat juga Hapip Abdul Djebar, Kamus Banjar-Indonesia (Jakarta: Pusat Pembinaan Dan Pengembangan Bahasa, Departemen Pendidikan Dan Kebudayaan, 1977), 58, 107, 206, dan 243. Yakni bisa lihat pada halaman 58 (tentang sagati), 107 (tentang kamarian), 206 (tentang rangit), dan 243 (tentang susudu).

${ }^{63}$ Tentang pembuktian keterpengaruhan dalam perspektif historis, lihat Louis Gottschalk, Understanding History: A Primer of Historical Method (New York: Alfred A. Knoff, 1964), 249-250.

64“Asal-usul Penduduk Berau," diakses 26 Mei 2018, https://warkopdangkita,blogspot.co.id/2015/05/asal-usul-penduduk-berau.html?m=1.

${ }^{65}$ Kata "negeri", dalam hal ini padanannya dalam bahasa Banjar, "nagari", sebenarnya juga digunakan, namun tidak populer di kalangan masyarakat Banjar. 
benar-benar ingin mengusir kalian dari negeri kami (ardhinâ), atau kalian mau kembali kepada agama kami". Kata "ardbinâ" (negeri kami, banua kami) dalam ayat itu diganti dengan kata "qaryatinâ" pada Q.s. al-A'râf: 88 yang juga berbicara tentang tema yang sama, yaitu pengusiran Nabi Syu'aib dari tempat tinggalnya oleh orang-orang kafir. Itu artinya adalah bahwa kata "ardh" di sini tidak bermakna "bumi" secara umum, melainkan "tanah atau tempat tinggal kami" (our land), ${ }^{66}$ dan secara kontekstual adalah sebutan bagi daerah yang dihuni dan dikuasai oleh orang-orang kafir penentang Nabi Syu'aib, di mana identitas (agama) dalam hal ini adalah satu dan menjadi penghubung secara primordial antaranggota dalam kelompoknya. Kedua ayat ini, begitu juga rangkaian ayat-ayat lain yang terkait, turun untuk menceritakan tentang pengingkaran orang-orang kafir terhadap risalah kenabian yang disampaikan kepada mereka. Oleh karena itu, makna konotatifnya tampak negatif, karena kata itu menjadi lekat dengan solidaritas kelompok penentang Nabi. Konteks kata ini menjadi berkonotasi negatif hanya karena berada dalam konteks cerita pengingkaran orang-orang kafir tersebut. Akan tetapi, apa yang ditunjukkan di sini adalah bahwa kata tersebut adalah kata yang berkonotasi primordial, sama halnya dengan terjemahnya, "banua", tidak berarti bahwa secara keseluruhan ikatan primordial itu menjadi negatif.

Ikatan primordial, dalam al-Qur'an, tidak selalu dianggap sebagai negatif seperti itu, karena ia diakui sebagai pengikat solidaritas masyarakat. Bahkan, dalam alQur`an, nilai-nilai budaya, termasuk solidaritas sosial, diakui melalui konsep 'urf. Kata urf semakna dengan ma'rûf.6. Menurut al-Râghib al-Ashfahâni, kedua kata ini mengandung pengertian setiap perbuatan yang nilai kebaikannya bisa diketahui dengan akal atau dengan penjelasan agama. ${ }^{68}$ Dengan demikian, salah satu aspek dari pertimbangan baik-buruk adalah akal, tidak hanya penjelasan dari wahyu. Produk dari akal adalah budaya. Budaya sendiri meliputi banyak wujud; dari produk teknik yang dihasilkan oleh manusia hingga produk pemikiran. Nah, ikatan primordialitas tidak seluruhnya menjadi negatif. Bahkan, sebagai bagian dari kultur, ikatan primordialitas yang mengingat anggota-anggota dalam masyarakat bisa menjadi elemen yang dipertimbangkan dalam penerapan ajaran-ajaran al-Qur`an. ${ }^{69}$ Ikatan primordialitas

${ }^{60}$ Muhammad Asad, The Message of the Qur'an (Gibraltar: Dâr al-Andalus, 1980), 217, 373.

${ }^{67}$ Ibrahim Unays et.al, al-Mu'jam al-W asith, vol. II (T.tp: Dâr al-Fikr, t.th), 595.

${ }^{68} \mathrm{Al}$-Râghib al-Ashfahâni, Mu'jam Mufradât Alfâz̆ al-Qur ân (Beirut: Dâr al-Syâmiyyah dan Damaskus: Dâr al-Qalam, 1992), 561.

${ }^{69}$ Hamka mengatakan, "Agama datang menuntun manusia dan memperkenalkan mana yang makruf itu dan mana yang munkar. Sebab itu, maka makruf dan munkar itu tidaklah terpisah dari pendapat umum. Kalau ada orang berbuat makruf, maka seluruh masyarakat menyetujui, membenarkan, dan memuji. Kalau ada perbuatan munkar, seluruh masyarakat menolak, membenci, dan tidak menyukainya. Sebab itu bertambah tinggi kecerdasan beragama, bertambah kenal akan yang makruf dan bertambah benci orang kepada yang mungkar." Lihat Hamka, Tafsir al-Az̧har, vol. IV (Jakarta: Penerbit Pustaka Panjimas, 1982), 40. Doktrin Islam sebagai tipe-ideal ketika bersentuhan dengan realitas sosial kemasyarakatan meniscayakan dijabarkannya ajaran-ajaran tersebut secara aplikatif. Perbedaan kondisi menghendaki juga perbedaan penjabaran itu. Nah, penjabaran sesuai dengan tradisi masyarakat yang tidak bertentangan dengan prinsip-prinsip ajaran Islam itulah yang disebut dengan 'urf atau ma'rûf. Lihat M. Quraish Shihab, Wawasan al-Qur'an (Bandung: Mizan, 1996), 343. 
adalah elemen yang tidak bisa disingkirkan dari manusia, seperti halnya ashabiyyah (fanatisme) sebagai kekuatan pengikat solidaritas kelompok, sebagaimana dikemukakan oleh Ibn Khaldûn. ${ }^{70}$

\section{Dimensi Partikularitas dan Universalitas dalam Terjemah al-Qur'an dalam Bahasa Banjar}

Sebagai bagian dari budaya, kearifan lokal (local wisdom) memiliki partikularitas dan memiliki sisi yang mungkin diangkat ke level universalitas. Dua sisi ini bisa menjadi titik-temu kritik kalangan agamawan maupun para ilmuwan sosial. Kalangan agamawan yang hanya melihat agama sebagai representasi wahyu semata cenderung akan menganggap budaya sebagai ancaman bagi pemurnian agama, karena rawan sinkretisme, karena ia tidak melihat dimensi yang menyejarah dari agama. Agama seakan hanya "sentral" (karena turun di Makkah dan Madinah) dan berlaku seluruhnya secara universal dengan begitu saja di ruang dan waktu yang berbeda, tidak melihat sisi "pinggir" (perifer). Sebaliknya, kalangan ilmuwan sosial yang reduksionis cenderung melihat agama hanya sebagai budaya dengan fenomena yang partikular.

Berikut aspek universalitas dan partikularitas kearifan lokal Banjar dalam alQur'an dan Terjemahnya Bahasa Banjar.

\begin{tabular}{clll}
\hline No. & \multicolumn{1}{c}{ Bentuk } & \multicolumn{1}{c}{ Partikularitas } & \multicolumn{1}{c}{ Universalitas } \\
\hline 1. & $\begin{array}{l}\text { Penyebutan Tuhan: "Pian", } \\
\text { "Sidin" }\end{array}$ & $\begin{array}{l}\text { Penghormatan terhadap } \\
\text { kalangan tua }\end{array}$ & $\begin{array}{l}\text { Penghormatan, } \\
\text { Penghambaan } \\
\text { kepada Tuhan }\end{array}$ \\
\hline 2. & "Jangan bacakut papa-daan" & $\begin{array}{l}\text {-Kekerabatan } \\
\text {-Fanatisme kekeluargaan }\end{array}$ & $\begin{array}{l}\text {-Persaudaraan } \\
\text {-Solidaritas }\end{array}$ \\
\hline 3. & "Banua" & -Solidaritas kedaerahan & -Persaudaraan \\
& & -Ikatan primordial & -Solidaritas \\
\hline
\end{tabular}

Tabel 2. Nilai dari Partikular ke Universal

Pengunaan "Pian" dan "Sidin" yang semula ditujukan kepada orang tua atau "dituakan" (dituhaakan, dihormati), yaitu kepada manusia, kini diterapkan kepada Tuhan. Namun, partikularitasnya dilucuti menjadi secara esensial menjadi penghormatan dan penghambaan kepada Tuhan. Bagi kalangan agamawan, kekhawatiran muncul karena dianggap akan terjerumus ke syirk, yaitu menyamakan Tuhan dengan makhluk. Namun, kandungan dari ungkapan tersebut tidak seluruhnya diterapkan kepada Tuhan, karena di samping ada partikularitas kandungannya, juga ada sisi universalitas yang terkandung dalam ungkapan tersebut, yaitu penghormatan dan penghambaan kepada Tuhan. Makna partikularnya adalah penghormataan terhadap orang tua atau orang yang dihormati di keluarga, di pergaulan, dan di masyarakat, sedangkan makna universalnya adalah penghormatan, dan kini diterapkan kepada Tuhan.

70Ibn Khaldûn, Muqaddimah (Beirut: Dâr al-Fikr, t.th), 313. 
"Jangan bacakut papadaan" sebenarnya adalah kearifan lokal yang tentu dari partikularitasnya terbatas pada kekerabatan dan fanatisme kekeluarga atau kesukuan. Namun, inti dari kearifan itu sebenarnya adalah solidaritas dan persaudaraan. Konsep "papadaan" dalam faktanya sering diperluas dengan mencari dangsanak angkat (saudara angkat) atau kuitan angkat (orang tua angkat) yang juga dianggap sebagai bagian dari kerabat. "Papadaan" (sesama saudara/ keluarga) menunjukkan adalah solidaritas yang tinggi di tengah masyarakat Banjar. Nilai partikular ini bisa menjadi pengikat antarelemen dalam masyarakat, bahkan bisa menjadi media penyelesaian jika terjadi konflik antar sesama warga dalam komunitas Banjar, atau dalam ikatan silsilah keluarga.

Begitu juga, konsep "banua" merupakan konsep yang berisi ikatan primordial kedaerahan, karena sebagai sebagai tempat seseorang lahir, dibesar, bergaul, dan memakai identitas dan tata moral setempat. Sekalipun solidaritas kedaerahan, sebagaimana halnya solidaritas kelompok ('ashabiyyah), bisa menjurus kepada hal-hal negatif, tidak seluruhnya bersifat negatif. Bahkan, solidaritas ini menjadi pengikat secara positif antarkomponen warga dari suku yang sama. Sisi universalitas "banua" sebenarnya adalah persaudaraan dan solidaritas.

Penghormatan, solidaritas, dan persaudaraan adalah nilai-nilai universal yang terdapat dalam etika Banjar yang terepresentasi dalam tiga hal di atas. Nilai-nilai ini mengandung norma etika yang bersifat absolut yang berlaku secara universal, tidak terikat dengan ruang dan waktu. Masyarakat Banjar akan memiliki rasa hormat, solodaritas, dan persaudaraan terhadap orang di luar mereka. Penghormatan itu sebagaimana diterapkan kepada manusia, juga diterapkan kepada Tuhan, namun dalam substansi yang berbeda. Penghormatan itu, dalam konteks penerapannya terhadap Tuhan, mengandung perasaan $t a^{\prime} ₹ h \hat{\imath}$ (pengagungan) sekaligus perasaan kagum (dalam ungkapan psikologi agama sebagai diistilahkan oleh Rudolf Otto, mysterium tremendum pascinan). ${ }^{71}$ Dimensi ini menjadi kesadaran yang bersifat inheren pada manusia dan bersifat universal. Universalitas itu bermakna bahwa ada absolusitas dalam etika Banjar, sehingga "etika situasional", yaitu nilai baik dan buruk ditentukan oleh situasi, tidak ada norma etika yang berlaku universal (absolut), ${ }^{72}$ tidak dianut oleh urang Banjar yang meski sangat tradisional. Norma etika yang dianut di sini bersifat kategoris, tidak bersyarat, yaitu homati siapa saja yang harus wajib dihormati. Hanya saja, pengertian "penghormatan" terhadap manusia berbeda muatannya dengan "penghormatan" (ta'₹̧im dan penghambaan) terhadap Tuhan. Hal itu karena ada relativitas kultural, karena penghormatan terhadap sesama dalam masyarakat memiliki kekhasan tertentu.

${ }^{71}$ Lihat Rudolf Otto, The Idea of the Holy: an Inqury into the Non-rational Factor in the Idea of the Divine and Its Relation to the Rational, trans. John W. Harvey (London, Oxford, dan New York: Oxford University Press, 1958).

72“Situational ethics - Wikipedia,”, https://en.m.wikipedia.org/wiki/Situational_ethics. diakses 4 Oktober 2019 


\section{Simpulan}

Tidak benar bahwa kearifan sebagai pengetahuan lokal bisa dikontraskan secara rigid dengan pengetahuan yang selama ini dianggap "universal dan berlaku umum" dalam pengertian, misalnya, dalam konteks agama, seperti Islam, sebagai pengetahuan yang berasal dari wahyu yang setidaknya berlaku umum untuk pemeluknya. Dalam konteks secara umum, tidak bisa memperhadapkan secara diametral antara kearifan lokal dan agama.

Kontras itu tidak mungkin terjadi, terlihat dari terjemah al-Qur`an ke bahasa Banjar ini. Ada kearifan lokal yang berdimensi partikular, tapi tetap terhubung dengan dimensi universalnya. Pertama, ditemukan beberapa bentuk kearifan lokal dalam konteks ini, yaitu: (1) penggunaan kata ganti orang (pronoun), seperti pian (Engkau) dan sidin (Dia) sebagai ungkapan lebih halus daripada ikam dan inya, (2) larangan berseteru karena prinsip kekerabatan yang kuat dalam masyarakat Banjar, misalnya, melalui terjemah "jangan bacakut" dari ungkapan lâ tatafarraqû, (3)

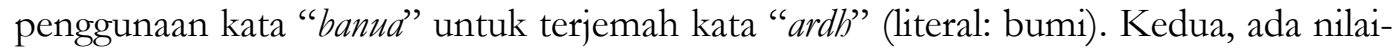
nilai moral yang merupakan pengetahuan atau nilai partikular yang berlaku setempat yang mendasari penggunaan ungkapan-ungkapan tersebut, yaitu: (1) penghormatan terhadap orang yang lebih tua (tatuba) atau yang "dituakan", yaitu dianggap sebagai pemimpin atau orang yang diteladani (tutuha), (2) menjunjung tinggi prinsip kekerabatan yang kuat (papadaan) dan solidaritas yang kuat antarsesama, baik dalam keluarga maupun sesama suku, dan (3) menjunjung tinggi solidaritas daerah dan ikatan priomordial kedaerahan yang menghubungkan antarwarga, meski sedang di luar daerah. Pengetahuan atau nilai partikular itu, dalam konteks terjemah al-Qur an berbahasa Banjar ini, diangkat atau diterapkan ke level yang lebih universal dengan melucuti aspek lokalitas, kedaerahan, dan kesukuannya menjadi penghormatan, persaudaraan, dan solidaritas. Universalisasi nilai-nilai partikular inilah yang menjadi dasar bagi suku Banjar untuk bisa berdiaspora dan melebur di daerah dan suku lain. Dengan demikian, dalam nilai-nilai partikular ada dimensi yang bersifat universal yang bisa melebur dengan etika lain pada suku berbeda. Begitu juga, etika yang bersifat universal memiliki sisi partikularnya. Dalam konteks pertama, etika Banjar kemudian tidak didasarkan atas etika situasional, karena sebagai komunitas Muslim yang agamis, masyarakat Banjar berpatokan pada ukuran etika yang jelas, yaitu melalui kultur yang dikembangkan yang tetap harmoni dengan etika al-Qur`an.

Hal ini juga dibuktikan dari beberapa riset terdahulu, misalnya, riset Ahmad Rafiq, bahwa meskipun komunitas Muslim Indonesia (dalam hal ini direpresentasi oleh masyarakat Muslim Banjar) memiliki banyak tradisi pengamalan (dimensi performatif atau fungsional) al-Qur`an, sebagai komunitas Muslim "pinggiran"--jika dilihat dari Timur Tengah sebagai "sentral, pusat" turunnya wahyu dan perkembangan awal Islam--tidak berarti bahwa praktik itu dianggap jauh dari alQur`an. ${ }^{73}$ Begitu juga, tulisan Rezqan Noor Farid, mengukuhkan hal yang sama, yaitu bahwa ada tradisi, dalam pengertian yang luas sebagai tradisi lisan dan tertulis, yang

${ }^{73}$ Lihat kembali Rafiq, “The Reception of the Qur'an...” 
bersifat Qur âni. ${ }^{74}$ Dengan istilah lain, ada dua sisi yang saling berinteraksi dalam hubungan antara al-Qur'an dan kultur (termasuk nilai dan kearifan lokal di dalamnya), yaitu proses enkulturasi al-Qur`an, untuk mengatakan telah terjadi pribumisasi, di mana al-Qur an dan ajarannya terbudayakan atau membudaya menjadi "al-Qur ân kultural"--dalam pengertian yang tidak sama seluruhnya dengan al-Qur ân sebagai produk budaya Nashr Hâmid Abû Zayd--dan proses islamisasi kultur, di mana al-Qur ân dan ajarannya diserapkan oleh kultur, yang melahirkan "kultur Qur'âni". ${ }^{75}$ Benar kesimpulan Alfani Daud bahwa masyarakat Banjar pada dasarnya adalah masyarakat yang taat beragama, namun berberapa praktik tidak memiliki referensi dari ajaran Islam, melainkan dicari dari budaya ${ }^{76}$ jika yang dimaksud adalah kultur atau budaya sebagai praktik-praktik keagamaan. Namun, di sisi lain, budaya dalam bentuk pemikiran (peradaban, civilization), seperti tergambar dalam terjemah ini, terlihat ada kelekatan antara wahyu dan budaya.

Masuknya muatan lokal berupa nilai-nilai moral kearifan dalam terjemah ini adalah karena memang kultur masuk ke dalam proses ketika penerjemah memilih ungkapan kata yang tak syak lagi merupakan pilihan budaya. Di samping itu, secara epistemologis, terjemah bukanlah semata aktivitas mekanik, yaitu memindahkan kata ke kata lain, melainkan lebih dari itu, bahwa terjemah adalah bagian dari, atau bahkan hasil dari menafsirkan. Meski hanya disebut sebagai terjemah, bukan tafsir, masukan budaya tetap terjadi, karena bagian dari terjemah adalah upaya menafsirkan, sehingga dikenal ada istilah tarjamah tafsiriyyah, di mana pemilihan kata akan merepresentasikan muatan budaya, karena bahasa adalah bagian dari budaya. Muatan kearifan lokal tersebut bukanlah mengurangi representasi makna, apalagi mengurangi sakralitas alQur`an, melainkan justeru menerjemahkan ajaran-ajaran al-Qur`an agar bisa dipahami oleh warga lokal, bahkan memberikan muatan baru dari aspek budaya ke penjabaran makna al-Qur`an. Bagaimanapun juga, ajaran-ajaran al-Qur`an mesti, meminjam ungkapan Fazlur Rahman, "dilabuhkan sauhnya ke dataran realitas ruang dan waktu" (anchoring revelation in space and time). Jadi, budaya dan al-Qur'an adalah dua sisi yang berinteraksi secara kreatif, sama halnya bahwa partikularitas saling terhubung dengan universalitas.

\section{Daftar Pustaka}

Abdul Djebar, Hapip. Kamus Banjar-Indonesia. Jakarta: Pusat Pembinaan Dan Pengembangan Bahasa, Departemen Pendidikan Dan Kebudayaan, 1977.

AF, Ahmad Gaus. Sang pelintas batas: biografi Djoban Effendi. Jakarta: ICRP dan Penerbit Buku Kompas, 2009.

\footnotetext{
${ }^{74}$ Lihat kembali Farid, "Wisdom Values," 56.

${ }^{75}$ Wardani, “al-Qur`an Kultural dan Kultur Qur`ani: Interaksi antara Universalitas, Partikularitas, dan Kearifan Lokal," al-Tahrir 15, no. 1 (2015): 132-34.

${ }^{76}$ Daud, Islam dan masyarakat Banjar, 581.
} 
Amin, Berkatullah. "Pendekatan Konseling Eksistensi Humanistik berbasis nilai Budaya Banjar 'Wasaka' dalam membentuk karakter siswa di Banjarmasin." Dalam Prosiding Seminar Nasional Bimbingan dan Konseling, 2:89-98, 2018.

Amursid, M. "Hermeneutika Al-Qur'an A Syâthibî; Telaah Gagasan al- Syâthibî tentang Signifikasi Ke-Araban al-Qur'an." Analisis: Jurnal Studi Keislaman 16, no. 2 (2016): 169-188.

Annajah, Masyithah. "Dirâsah 'an Manhaj al-Tafsîr al-Mawdhû̂î ind al-Ustâ alDuktûr Muhammad al-Gazâlî al-Banjarî fî Kutubih.” Skripsi S1. Banjarmasin: Fakultas Ushuluddin dan Humaniora UIN Antasari, 2017.

Arbain, Taufik. Strategi Adaptasi Migran Banjar. Yogyakarta: LKIS, 2009.

Asad, Muhammad. The Message of the Qur' $n$. Gibraltar: Dâr al-Andalus, 1980.

“Asal-usul Penduduk Berau." Diakses 26 Mei 2018. https://warkopdangkita,blogspot.co.id/2015/05/asal-usul-penduduk-berau.html?m=1.

Ashfahâni, Al-Râghib al-. Mu'jam Mufradât Alfẫ̧h al-Qur ân. Beirut, Damaskus: Dâr al-Syâmiyyah, Dâr al-Qalam, 1992.

Azizah, Noor. "Djohan Effendi's Method in Formulating the Essence of the Qur'an in His Book Pesan-pesan al-Qur'an Mencoba Mengerti Intisari Kitab Suci." Skripsi S1 Fakultas Ushuluddin dan Humaniora. Banjarmasin: UIN Antasari Banjarmasin, 2014.

Azmy, Khalilah Nur. "Metode Penerjemahan al-Qur`an dalam Bahasa Banjar (Studi Analisis terhadap al-Qur'an Terjemah Bahasa Banjar)." Skripsi S1. Banjarmasin: Fakultas Ushuluddin dan Humaniora UIN Antasari, 2018.

Bafadal, Fadhal Ar, dan Rosehan Anwar. Mushaf-mushaf kuno Indonesia. Vol. 1. Puslitbang Lektur Keagamaan, Badan Litbang Agama dan Diklat Keagamaan ..., 2005.

"Bahasa Banjar dalam Wikipedia bahasa Indonesia, ensiklopedia bebas." Diakses 26 Mei 2020. https://id.m.wikipedia.org/wiki/Bahasa_Banjar_(26.

Bahasa, Departemen Pendidikan Nasional Pusat. "Kamus Bahasa Banjar Dialek Hulu Indonesia." Banjarmasin: Balai Babasa, 2008.

Baidan, Nashruddin. "Problematika Penerjemahan al-Qur an dalam Bahasa Indonesia." Indonesian Journal of Islamic Literature and Muslim Society 2, no. 1 (2017): 1-20.

"Banua - Wikipedia bahasa Indonesia, ensiklopedia bebas." Diakses 26 Mei 2020. https://id.m.wikipedia.org/wiki/Banua.

Burhani, Ahmad Najib. "Sectarian Translation of the Qur'an in Indonesia: The Case of the Ahmadiyya." Al-Jami'ab: Journal of Islamic Studies 53, no. 2 (2015): 251282.

Daud, Alfani. Islam dan masyarakat Banjar: Deskripsi dan Analisa Kebudayaan Banjar. Jakarta: RajaGrafindo Persada, 1997.

D'Silva, Patrick J. "Tafs $\mathrm{r}$ and Islamic Intellectual History: Exploring the Boundaries of a Genre Edited by Andreas Görke and Johanna Pink. Qur'anic Studies Series, 12. London: Oxford University Press in association with the Institute of Ismaili Studies, 2014. Pp. xxi+ 547; appendixes. Hardcover, \$99.00.” Religious Studies Review 43, no. 1 (2017): 71-72. 
Effendi, Djohan. Pesan-Pesan Al-Qur'an: Mencoba Mengerti Intisari Kitab Suci. Jakarta: PT. Serambi ilmu Semesta, 2012.

Effendi, Rustam. "Eksistensi Sastra Lisan Mahalabiu bagi Masyarakat Banjar Kalimantan Selatan." LITERA 11, no. 2 (2012).

Faizin, Hamam, dan Arsyad Sobby Kesuma. "Pemikiran Tafsir Djohan Effendi." KALAM 11, no. 2 (2017): 455-488.

Farid, Rezqan Noor. "Wisdom Values in the Banjarese Proverbs." Parole: Journal of Linguistics and Education 5, no. 1 (2015): 50-66.

Gorke, Andreas. "Redefining the Borders of Tafs r: Oral Exegesis, Lay Exegesis and Regional Particularities." Tafs $r$ and Islamic Intellectual History: Exploring the Boundaries of a Genre, 2014, 363-80.

Gottschalk, Louis. Understanding History: A Primer of Historical Method. New York: Alfred A. Knoff, 1964.

Griffel, Frank. "Al-Ghazali, Averroes and the Interpretation of the Qur'an: Common Sense and Philosophy in Islam." Journal of Islamic Studies 23, no. 1 (2012).

Hadi, Sumasno. Etika Banjar. Banjarmasin: Lambung Mangkurat University Press, 2017.

Hakim, Arif Rahman. "Urang Banjar Asli, Urang Banjar Keturunan dan Jarwo." Diakses $17 \quad$ April $2020 . \quad$ https://idr.uinantasari.ac.id/6268/1/Urang\%20Banjar\%20Asli\%2C\%20Urang\%20Banjar\% 20Keturunan $\% 20$ dan\%20Jarwo.pdf.

Halimatus, Sa'diah. "Manhaj Tafsîr Tim Sahabat Kandangan (Dirâsah Manhajiyyah fî Tafsîr Juz' 'Amma)." Skripsi S1. Banjarmasin: Fakultas Ushuluddin dan Humaniora UIN Antasari, 2017.

Hamka. Tafsir al-Az̧har. Vol. IV. Jakarta: Penerbit Pustaka Panjimas, 1982.

Harun, Salman. Mutiara al-Qur'an: Aktualisasi Pesan al-Qur'an dalam Kebidupan. Jakarta: Logos Wacana Ilmu, 1999.

Hassan, A. al-Furqan = Tafsir Qur'an. Kota Bharu, Malaysia: Pustaka Aman Press, 1971.

. al-Furqan = Tafsir Qur'an. Jakarta: Universitas al-Azhar Indonesia, 2010.

Hegel, Christian. "An Early Anonymous Greek Translation of the Qur'an: The Fragments from Niketas Byzantio's Refutatio and the Anonymous Abjuratio." Collectanea Christiana Orientalia., Collectanea Christiana Orientalia., 7 (2010).

Indradi, Arsyad. "Khazanah Makna Kata Bahasa Banjar: Peribahasa dalam Bahasa Banjar." Khazanah Makna Kata Bahasa Banjar (blog), 2 Agustus 2008. http://khazmakata.blogspot.com/2008/08/peribahasa-dalam-bahasabanjar.html.

Indriyana, Nur. "Diaspora Suku Banjar di Tanjung Jabung Barat (Studi Kasus Di Kuala Tungkal 1905-1945).” Skripsi S1. Jambi: Universitas Jambi, 2017. 
Ingglis, Jhonny. "40 Kosa Kata Bahasa Banua Lengkap dan Artinya." Diakses 26 Mei 2018. https://www. tamanbahasa.com/40-kosa-kata-bahasa-banua-lengkapdan-artinya-513.

Istianah, Istianah. "Dinamika Penerjemahan Al-Qur'an: Polemik Karya Terjemah AlQur'an HB Jassin dan Tarjamah Tafsiriyah Al-Qur'an Muhammad Thalib." MAGHZA: Jurnal Ilmu Al-Qur'an dan Tafsir 1, no. 1 (2016): 41-56.

Johns, Anthony H. "Islam in the Malay World: An Exploratory Survei with Some Reference to Quranic Exegesis" dalam Islam in Asia, Vol. II, Southeast and East Asia, edited by Raphael Israeli and Anthony H." Johns. Jerusalem: The Magnes Press, The Hebrew University, 1984.

“Kemenag Kembali Luncurkan Al-Qur`an Terjemah Tiga Bahasa Daerah.” Diakses 25 Maret 2019. http://m.santrinews.com/Nasional/8764/KemenagKembali-Luncurkan-Al-Qur`an-Terjemah-Tiga-Bahasa-Daerah.

"Kemenag Luncurkan Alquran Terjemah Bahasa Aceh." Diakses 9 Juni 2020. http://www.ar-raniry.ac.id/index.php/id/posts/kemenag-luncurkan-alquranterjemah-bahasa-aceh.

"Kemenag Mulai Proses Penyusunan Terjemah Al-Quran Berbahasa Madura | Dinas Komunikasi dan Informatika Provinsi Jawa Timur.” Diakses 25 Maret 2019. http://kominfo.jatimprov.go.id/read/umum/-kemenag-mulai-prosespenyusunan-terjemah-al-quran-berbahasa-madura.

Khaldûn, Ibn. Muqaddimah. Beirut: Dâr al-Fikr, t.th.

“Mahalabiu." Diakses 3 Mei 2020. https://id.m.wikipedia.org/wiki/Mahalabiu.

"Mengukur Eksistensi Bahasa Banjar Dari Karya Sastra Hingga Karya Akademik jejakrekam.com." Diakses 2020. https://jejakrekam.com/2019/12/28/mengukur-eksistensi-bahasa-banjardari-karya-sastra-hingga-karya-akademik/.

Muhammad, Muhammad. "Dinamika Terjemah Al-Qur'an (Studi Perbandingan Terjemah Al-Qur'an Kemenerian Agama RI dan Muhammad Thalib)." Jurnal Studi Ilmu-ilmu Al-Qur'an dan Hadis 17, no. 1 (2018): 1-24.

Muhsin, Imam. Al-Qur'an dan budaya Jawa dalam tafsir al-Huda karya Bakri Syabid. Yogyakarta: eLSAQ Press, 2013.

Munadi, Fathullah. "Mushhaf Qira'at Syekh Muhammad Arsyad al-Banjarî dalam Sejarah Qira'at Nusantara" 9, no. 1 (2010).

- Syekh Mubammad Arsyad al-Banjarî dalam Konteks Kajian al-Qur'an di Nusantara. Banjarmasin: IAIN Antasari Press, 2011.

Nadhiroh, Wardatun. "kitab sanjata mu'min Sebuah Bentuk Tafsir Awam di Tanah Banjar." SUHUF Jurnal Pengkajian Al-Qur'an dan Budaya 11, no. 1 (2018): 119_ 143.

. Tradisi Kelisanan dan Keaksaraan al-Qur'an di Tanah Banjar. Banjarmasin: Antasari Press, 2018.

Noorhaidi. "Muhammad Arshad al-Banjari (1710-1812) and the Discourse of Islamization in the Banjar Ultanate." Tesis S2. Leiden: Universitas Leiden, 1999. 
Otto, Rudolf. The Idea of the Holy: an Inqury into the Non-rational Factor in the Idea of the Divine and Its Relation to the Rational, trans. John W. Harvey. London, Oxford, dan New York: Oxford University Press, 1958.

Perdana, Nizar. "Kiprah dan Pemikiran Tafsir Prof. Dr. H. Abdullah Karim, M.Ag." Skripsi S1. Banjarmasin: Fakultas Ushuluddin dan Humaniora UIN Antasari, 2016.

"Pesan-Pesan Alquran: Mencoba Mengerti Intisari Kitab Suci Karya: Djohan Effendi (Studi Kitab Tafsir) - Kumpulan Tulisan Hanief Monady.” Diakses 8 Juni 2020. https://haniefmonady.wordpress.com/2015/11/01/pesan-pesanalquran-mencoba-mengerti-intisari-kitab-suci-karya-djohan-effendi-studikitab-tafsir/.

Rafiq, Ahmad. "The Reception of the Qur'an in Indonesia: A Case Study of the Place of the Qur an in a Non-Arabic Speaking Community." Disertasi Ph.D. Philadelphia: Temple University, 2014.

Rijali, Ahmad. "Kandungan Budaya Bahasa Melayu Banjar dalam Kitab Sabîl alMuhtadîn Karya Syekh Muhammad Arsyad al-Banjarî." Laporan Hasil Penelitian. Banjarmasin: Lembaga Penelitian dan Pengabdian kepada Masyarakat, 2015.

Rinkes, D. A. Abdoerroef van Singkel: Bijdrage tot de Kennis van de Mystiek op Sumatra en Java. Heerenven: Hepkema, 1909.

Said, Muh. "Metodologi Penafsiran Sufistik: Perspektif Al-Gazali." Jurnal Diskursus Islam 2, no. 1 (2014): 142-168.

Saifuddin, Dzikri Nirwana, dan Norhidayat. Pengarub Unsur-unsur Budaya Lokal dalam al-Qur an dan Terjemahnya Babasa Banjar. Banjarmasin: Antasari Press, 2018.

Santosa, Iman Budhi. Kumpulan peribahasa Indonesia dari Aceh sampai Papua: untuk SD, SMP, SMA \& umum. Jakarta: Kawahmedia, 2009.

Sari, Yuliati Puspita. "KECERDASAN EMOSIONAL ORANG BANJAR DALAM PANTUN BANJAR." Sawerigading 20, no. 1 (2015).

Scheuer, Jacques. "Avital Wohlman, Contrepoint entre le sens commun et la philosophie en Islam. Ghazali et Averroès. Traduction par Annie Laurent, 2008." Revue Théologique de Lowvain 39, no. 4 (2008): 567-567.

Shihab, M. Quraish. "Membumikan al-Qur'an jilid 2: Memfungsikan wahyu dalam kehidupan." Jakarta: Lentera Hati, 2011.

. Wawasan al-Qur an. Bandung: Mizan, 1996.

Singkel, Abd al-Ra ûf. Tarjumân al-Mustafid. Beirut: Dâr al-Fikr, 1990.

"Situational ethics - Wikipedia." Diakses 4 Oktober 2019. https://en.m.wikipedia.org/wiki/Situational_ethics.

Sjamsuddin, Helius. Pegustian dan Temenggung: akar sosial, politik, etnis, dan dinasti perlawanan di Kalimantan Selatan dan Kalimantan Tengah, 1859-1906. Balai Pustaka, 2001.

Syahruni. "Pemikiran Tafsir Ahmad Gazali dalam Karyanya al-Qur`an: Tafsir Ayatayat Iptek." Skripsi S1. Banjarmasin: Fakultas Ushuluddin dan Humaniora UIN Antasari, 2017. 
Syukur, M. Asywadie. "Risalah Tubfah al-Râghibîn", dalam Khazanah Intelektual Islam Ulama Banjar, ed. Masdari dan Zulfa Jamalie. Banjarmasin: Pusat Pengkajian Islam Kalimantan, 2003.

Nahimunkar. "Terjemah Al-Qur'an Bahasa Tegal diluncurkan mahasiswa." Diakses 25 Maret 2019. https://www.nahimunkar.org/terjemah-al-quran-bahasategal-diluncurkan-mahasiswa/.

Tim Penerjemah. al-Qur'an dan Terjemabnya Bahasa Banjar. Jakarta: Puslitbang Lektur dan Khazanah Keagamaan Badan Litbang dan Diklat Kementerian Agama, 2017.

Tripa, Sulaiman. Peradilan Gampong. Banda Aceh: Bandar Publishing, 2019.

Ulbricht, Manolis. "The First Translation of the Qur'an (8th/9th century A.D.) and Its Use in the Anti-Islamic Work of Nicetas of Byzantium (9th c.)," 1 April 2020.

https://www.hse.ru/data/2012/07/02/1254237135/Ulbricht\%20RP.pdf.

Unays et.al, Ibrahim. al-Mu'jam al-Wasith. Vol. II. T.tp: Dâr al-Fikr, t.th.

Wardani. "al-Qur'an Kultural dan Kultur Qur`ani: Interaksi antara Universalitas, Partikularitas, dan Kearifan Lokal." al-Tahrir 15, no. 1 (2015): 132-34.

. "Madam Ka Banua Urang: Beberapa Catatan Awal tentang Migrasi Suku Banjar, Proses, dan Penyebarannya. Kandil, Edisi 14, Tahun V (AgustusOktober 2007." Kandil 14 (Oktober 2007).

—. Maqâshid al-Syarîa he Sebagai Paradigma Ideal-Moral Tafsir al-Qur’an: Perspektif AlSyathibi. Banjarmasin: Antasari Press, 2018.

Wardani, Wardani. Trend Perkembangan Pemikiran Kontemporer: Metodologi Tafsir AlQur'an di Indonesia. Yogyakarta: Kurnia Kalam Semesta, 2017.

Watt, William Montgomery. Bell's Introduction to the Qur ân. Edinburgh: Edinburgh University Press, 1970.

Whittingham, Martin. Al-Ghazali and the Qur'an: one book, many meanings. Routledge, 2007.

Wohlman, Avital. Al-Ghazali, Averroës and the interpretation of the Qur'an: common sense and philosophy in Islam. Routledge, 2009.

Yahya, Mohamad. "Peneguhan Identitas dan Ideologi Majelis Mujahidin Melalui Terjemah Al-Qur'an." RELIGIA, 2018, 188-208.

Yulianto, Agus. "Nilai-nilai Luhur Budaya dalam Papadah Banjar di Kalimantan Selatan." Kibas Cenderawasib 15, no. 2 (2018).

Yunus, Mahmud. Tafsir Qur'an Karim. Ciputat: Mahmud Yunus wa Dzurriyyah, 2015.

Zarqânî, Muhammad 'Abd al-'Azhîm al-. Manâhil al-Irfân fi 'Ulûm al-Qur'ân. Vol. 2. Beirut: Dâr al-Fikr, t.th.

Zulkifli. "Makna Ungkapan Tradisional Daerah Banjar." Diakses 25 Mei 2020. https://banuahujungtanah.wordpress.com/2010/05/19/ungkapantradisional-orang-banjar/. 